\title{
Lidový knoflík ve Sbírce Waldes-Knoflíky
}

Kateřina Hrušková

\section{Folk Buttons in Waldes Collection-Buttons}

Abstract: The study focuses on the set of folk costume buttons from the preserved part of the Waldes Museum collection. The aim of the paper is to present the button set and its ongoing research potentional, both in the further study of the collection itself and in comparison to other similar objects in the Czech Republic and abroad. The study includes the results of the long-term research of the Waldes Museum button subcollection that is provided with an institutional support of Museum of Glass and Jewellery Jablonec nad Nisou.

Keywords: Button, jewellery, folk culture, Waldes Museum, Museum of Glass and Jewellery in Jablonec nad Nisou

\section{Úvod}

Knoflíky jsou specifickým druhem spínadla, jejichž prvotní rolí je být nedílnou a plně funkční součástí oděvu. Mnohé typy knoflíků, používané vně oděvu, mají rovněž funkci estetickou nebo identifikační. Stejně jako módní i lidové knoflíky bývají nepřehlédnutelnou ozdobou a někdy role estetická převládá. Na rozdíl od módní produkce nepodléhá lidový knoflík tak rychle změnám vzorů výrobní technologie nebo materiálu a v běhu času prochází jen pozvolným vývojem. I proto se knoflíky lidového oděvu řadí mezi vděčné objekty sběratelského zájmu, které lze studovat, sbírat i vystavovat jako reprezentanty lidové kultury. $\mathrm{V}$ tomto duchu $\mathrm{k}$ nim přistupovalo i Waldesovo muzeum knoflíků a spínadel v Praze-Vršovicích, jehož většinu dochovaného sbírkového fondu od roku 1973 spravuje Muzeum skla a bižuterie v Jablonci nad Nisou (dále MSB). Pražský továrník Jindřich Waldes, jehož jméno je spojeno s kovovými patentkami a světově známým podnikem Waldes \& Co. s mateřskou továrnou v Praze-Vršovicích, považoval knoflíky a spínadla oděvu obecně za relevantní ukazatele stavu kulturní vyspělosti dané společnosti. Dlouhodobě vyzýval ke studiu a vědeckému bádání tohoto fenoménu. Jeho vášeň pro knoflík vedla nejprve k budování soukromé sbírky a v roce 1916 k založení soukromého muzea, jehož obsáhlou expozici spatřila veřejnost o dva roky později. Významnou část muzejního fondu i expozice zahrnovala Sbírka národopisná, která obsahovala lidový knoflík, spínadla a související textil. Svou komplexností v mnoha ohledech naplňovala cíle Waldesova muzea nejvíce ze všech sbírek. Po skončení druhé světové války došlo ke znárodnění vršovické továrny i muzea jako její součásti. V důsledku dalšího využití a svěření do péče jabloneckému muzeu byl soubor rozdělen podle nového klíce na „knoflíky“ a "spínadla a oděvní doplňky", které vedl k novým cestám práce se sbírkovým materiálem, a právě knoflíkům začala být věnována pozornost jako samostatnému fenoménu. Tato studie se zaměřuje na kolekci knoflíků k lidovému oděvu, která obsahuje více než čtyři sta padesát předmětů $\mathrm{z}$ dochované sbírky Waldesova muzea. Cílem studie je představit soubor jako takový, upozornit na logické vazby s dalšími exponáty a s dosud ne zcela známou kolekcí vyobrazení v podobě tematických fotografií a grafik a nastínit jeho roli $\mathrm{v}$ rámci původní sbírky a odborných aktivit Waldesova muzea. $\mathrm{V}$ neposlední řadě chce studie upozornit na potenciál souboru jako komparačního a studijního materiálu pro práci s podobně zaměřenými sbírkami i pro samostatné studium knoflíků $\mathrm{k}$ lidovému oděvu. Cílem je i prezentace

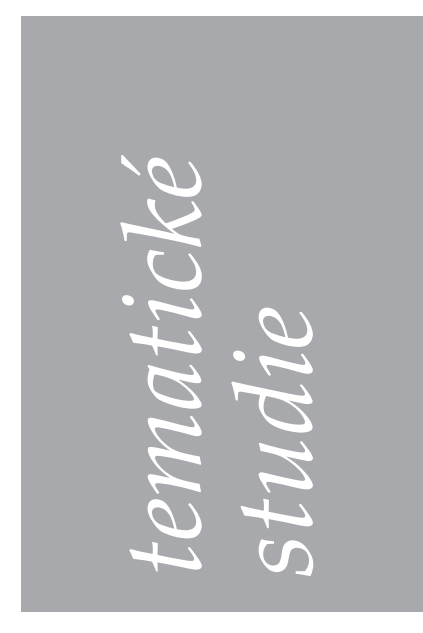

1 Sbírka Muzea skla a bižuterie $v$ Jablonci nad Nisou, číslo CES MSB/002-05-14/255002.

Mgr. Kateřina Hrušková Muzeum skla a bižuterie v Jablonci nad Nisou katerina.hruskova@ msb-jablonec.cz 
2 První ročník byl vydán s názvem Zprávy muzea knoflíků. Více se tématu vývoje názvu muzea a tím i proměně názvu periodika věnuje studie: KOENIGSMARKOVÁ,

Helena, WITTLICH, Filip. Uměleckoprümyslové museum

v Praze a Waldesovo muse-

um knofliků a spínadel všech dob - počátky spolupráce v letech 1916-1920. In: Sborník semináře $k 100$. výroči otevření

Waldesova muzea, Jablonec nad Nisou: Muzeum skla a bižuterie $v$ Jablonci nad Nisou -

Praha: Kotěrovo centrum architektury, 2018, s. 34-37.

3 Mezi další pomocné sbírky patřil Archiv negativů a dia-

positivů a Archiv historický a technologický, který obsahoval mimo jiné $i$ opisy a výtahy $z$ archivnich fondù nebo výpisy $z$ odborné literatury.

4 Dále existovala Sbirka vše-

obecného národopisu, která dokumentovala spínadla z mimoevropských oblastí.
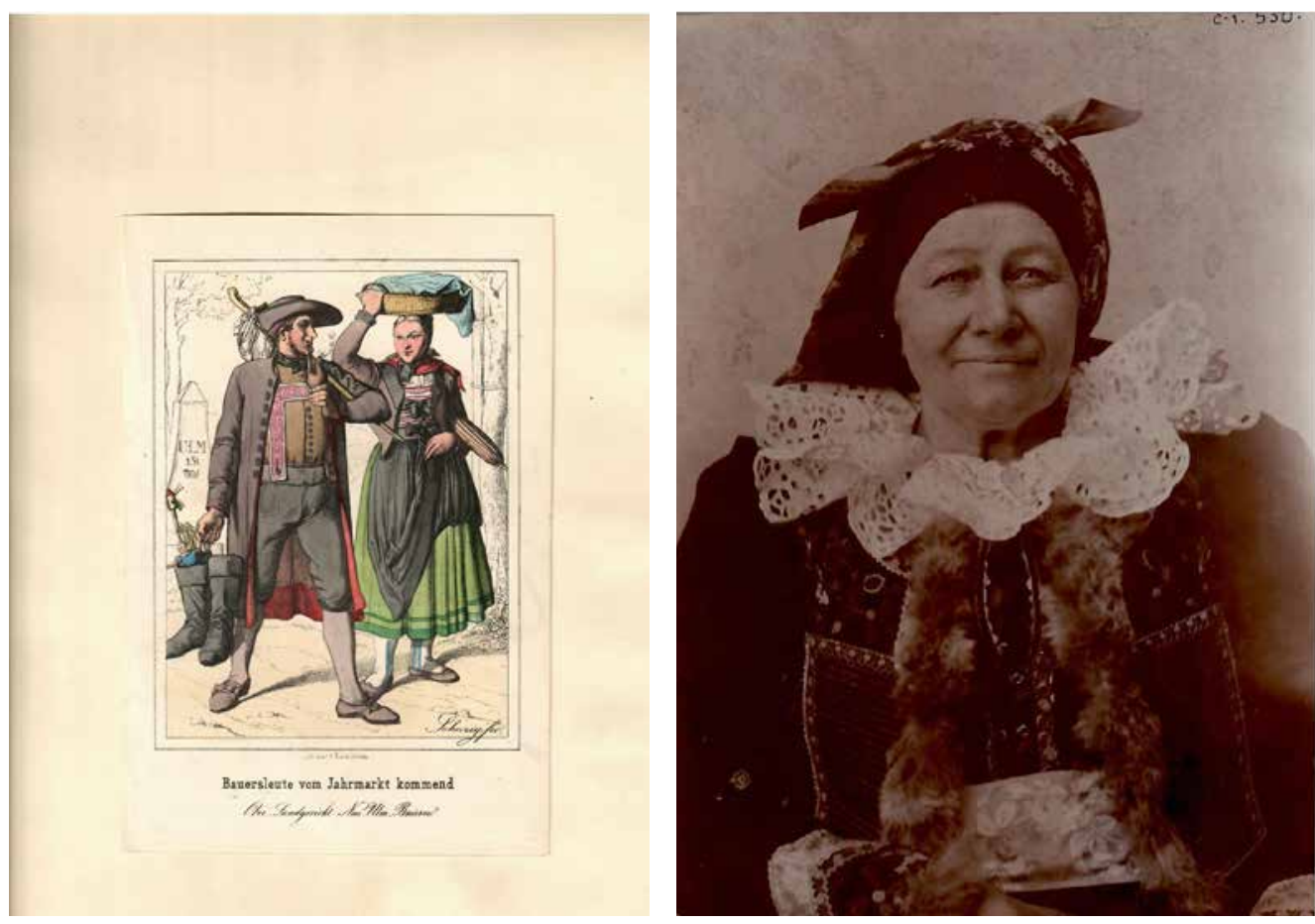

Obr. 1. Ukázka z Archivu krojového, tisk na papíre, Archiv Waldesova Muzea, Muzeum skla a bižuterie $v$ Jablonci nad Nisou, krabice 5

výsledků dlouhodobého odborné práce s podsbírkou Sbírka Waldes-Knoflíky, která probíhá na základě institucionální podpory dlouhodobého koncepčního rozvoje výzkumné organizace Muzeum skla a bižuterie v Jablonci nad Nisou poskytované Ministerstvem kultury ČR.

\section{Prameny a literatura $k$ tématu}

Studie vychází ze tř́ skupin zdrojů. Tím prvním je samotná podsbírka WaldesKnoflíky a vybrané související předměty z podsbírky Waldes-Spínadla a oděvní doplňky ${ }^{1}$. Druhou skupinu tvoří vybrané materiály z tzv. Archivu Waldesova muzea - pozůstatku kolekce s názvem Krojový archiv, který obsahuje rozmanitá vyobrazení spínadel, krojů a obyvatel v tradičních oděvech. Dnes je zachovaný materiál uložen v rámci tzv. Archivu Waldesova muzea (dále AWM), o který pečuje MSB. Při př́ípravě studie bylo rovněž čerpáno z odborné literatury zaměřené na lidový knoflík, šperk a oděv. Využitá periodika pocházejí z vlastní publikační činnosti Waldesova muzea, jedná se o časopis Zprávy Waldesova muzea ${ }^{2}$.

Archiv obrazového materiálu - tzv. Krojový archiv byl ve Waldesově muzeu budován paralelně se sbírkou trojrozměrných předmětů jako studijní i ilustrační
Obr. 2. Ukázka z Archivu krojového, "Stařena z Klobouk u Brna, Zimní úbor", fotografie, původní č. i. 530, Archiv Waldesova Muzea, Muzeum skla a bižute-

doplněk. Měl za úkol prezentovat knoflíky a další spínadla „, $\mathrm{v}$ přirozeném prostředí", tedy jako součást oděvu, a zároveň doplňoval chybějící trojrozměrné sbírkové předměty ${ }^{3}$. Obsahoval grafické listy, fotografie a kolorované kresby $\mathrm{k}$ tématu lidového oděvu, včetně systematické dokumentace sbírek dalších muzeí. Fotografie pocházejí především z Evropy, dominují německé regiony a oblasti Balkánu. Vedle fotografií obyvatel $\mathrm{v}$ tradičních oděvech jsou to exponáty nebo pohledy do expozic dalších muzeí. Fotografický materiál byl pro muzeum získáván od soukromých badatelů a odborníků nebo byl cíleně pořizován najatými fotografy. (Obr. 1, 2) Důležitým zdrojem informací je časopis Zprávy Waldesova musea vydávaný v letech 1916-1919. Již od 3./4. čísla prvního ročníku 1916 byly do časopisu zařazovány reporty o rozšiřování sbírek, které odkazují i na dary a nákupy lidových knoflíků. Od roku 1917 se zde objevují odkazy na konkrétní soubory předmětů, které dávají čtenáři obraz o obsahu sbírky co do jejího geografického a tematického vymezení. Knoflíky k lidovému oděvu stejně jako spínadla byly zařazeny do Sbírky lidopisné, později Sbírky národopisnét. Report samozrejmě neobsahoval celistvý výčet přírůstků, ale zajímavé kusy nebo rie $v$ Jablonci nad Nisou, krabice 6 
dary významných dárců. Podle popisu je možné i dnes některé př́růstky přesně identifikovat. Vybraná čísla obsahují také akviziční přehled s fotografiemi některých exponátů. Muzejní časopis je také jedním ze zdrojů informací o spolupráci s dalšími muzejními institucemi a nabízí přehled o př́růstcích v knihovně, Krojovém archivu nebo Technologickém archivu.

Ve Zprávách Waldesova muzea jsou čistě tématu lidových knoflíků věnovány pouze dvě studie a několik kratších zpráv. První studií byl text „Knoflík v lidovém kroji“ ${ }^{\prime 5}$ etnografky Rose Julien z Berlína, které v roce 1912 vyšla publikace Die deutschen Volkstrachten zu Beginn des 20. Jahrhunderts ${ }^{6}$. A jednou z řady ukázek, jak muzeum dokázalo spolupracovat $\mathrm{s}$ významnými odborníky své doby. Studie se věnuje knoflíku na lidovém oděvu $\mathrm{v}$ německém prostoru a je doprovázena bohatým obrazovým materiálem, fotografiemi i nákresy jak knoflíků z kovů, tak např́ílad z textilních vláken, které jsou rovněž ve sbírce zastoupeny. Některé $\mathrm{z}$ fotografií pořízených $\mathrm{R}$. Julien $\mathrm{v}$ rámci jejího etnografického výzkumu se staly součástí Krojového archivu. (Obr. 3) V čísle 1./2. trétího ročníku vyšla studie Jana Kouly „O spinadlech a lidovém kroji česko-slovenském ${ }^{\prime 7}$. Je zajímavá i proto, že $\mathrm{v}$ obrazové prŕloze prezentuje exponáty $z$ Waldesova musea. Je nutné podotknout, že některé $\mathrm{z}$ exponátů nejsou určeny správně a $\mathrm{k}$ obrazové př́loze se musí přistupovat kriticky. Studii doprovází i fotografie $\mathrm{z}$ archivu J. Kouly. Celé toto číslo Zpráv Waldesova muzea bylo tematicky zaměřené na lidová spínadla ${ }^{8}$. Část Př́spě̃uky obsahuje několik velmi kvalitních textů německých i tuzemských etnografů s bohatým obrazovým materiálem, např́íklad př́spěvek „Knoflíky a spony moravských Valachư"9 od Eduarda Domluvila z Valašského Meziříčí. V obrazové př́loze byl i kadlub $\mathrm{k}$ lití valašských kulovitých knoflíků. Jako jedno z mnoha typů spínadel jsou samozřejmě knoflíky zmiňovány i v dalších etnograficky zaměřených textech.

Jelikož cílem provedeného výzkumu bylo odborně zpracovat kolekci lidových

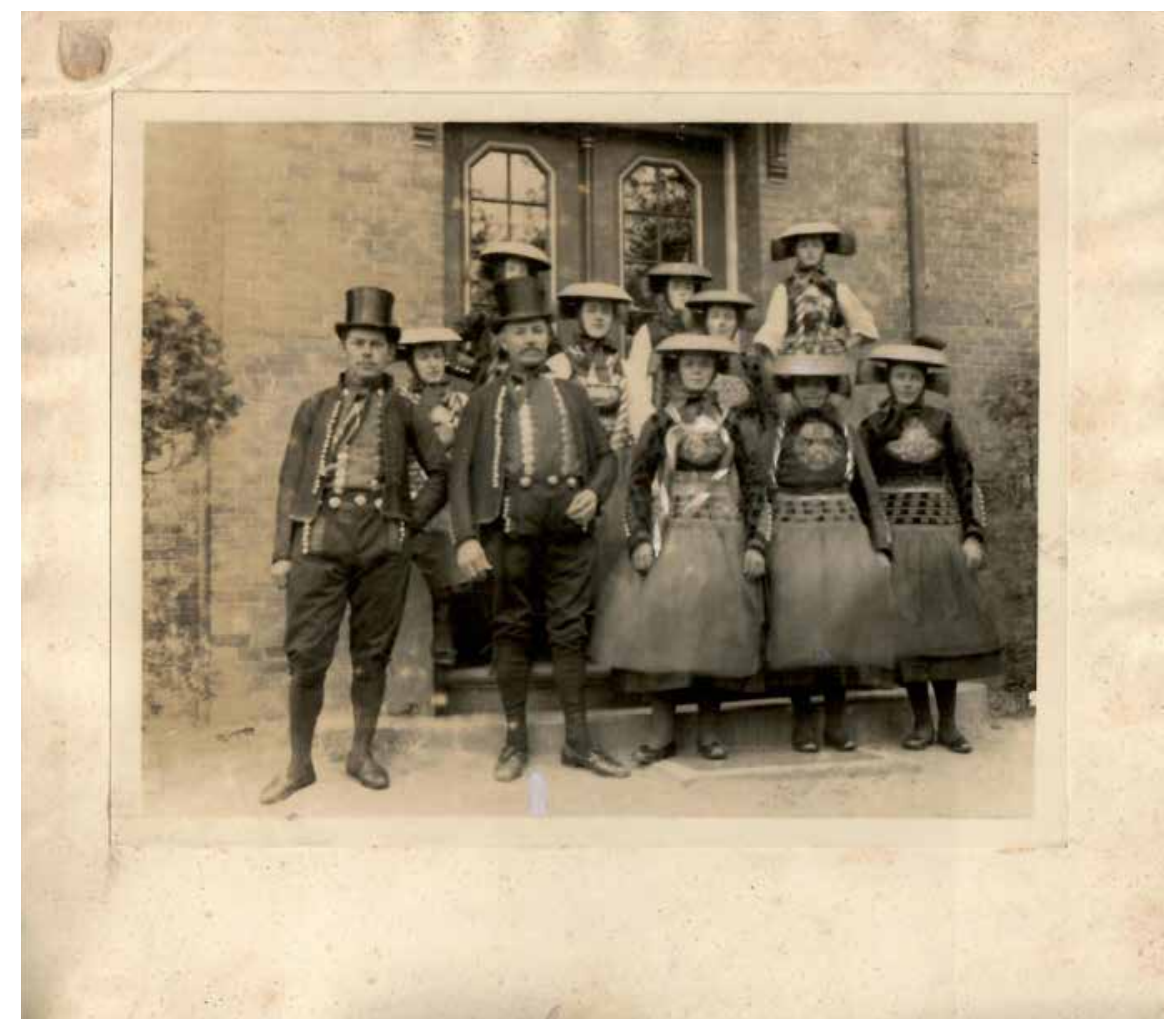

knoflíků, určit jejich původ a př́slušnost ke konkrétním tradičním oděvům, ověřit platnost dřívějších poznatků a zařadit dosud neurčené předměty, byla k tomuto účelu využita řada odborných publikací. Těch, které se zabývají výhradně lidovým knoflíkem, je poměrně málo, proto byly využity i publikace zaměřené obecně na lidový šperk a oděv. $V$ řadě publikací lze narazit na skutečnost, že knoflíkům není věnována dostatečná, někdy $\mathrm{v}$ podstatě nulová pozornost. $\mathrm{V}$ prrípadě publikací o kroji bývá akcent zaměřen především na textilie a textilní části oděvu, obuv nebo pokrývky hlavy. Knoflíky bývají v detailu popisovány i zobrazovány méně často nebo pouze na celém oděvu bez jemných detailů, spíše jen v náznaku. $\mathrm{V}$ př́padě publikací o lidovém šperku je větší prostor dán náhrdelníkům, sponám, prstenům nebo náušnicím. I tak lze tyto publikace velmi dobře využít, jelikož techniky zpracování a výtvarné motivy lidových šperků bývají podobné až identické se zpracováním knoflíků.

Níže uvedené tituly se knoflíku věnují výrazněji a je možné je $\mathrm{k}$ tomuto tématu doporučit. Pro získání obecné představy o pestrosti lidového knoflíku ze stř́bra je zcela jedinečnou publikace soukromé britské sběratelky Jane Perry, která patř́ mezi spolupracovnice Victoria \& Albert Museum v Lodýně. Kniha A Collector's
Obr. 3. Ukázka z Archivu krojového, Kroj Friesland'anů z oblasti Hamburku, fotografka: Rose Julien, Archiv Waldesova Muzea, Muzeum skla a bižuterie $v$ Jablonci nad Nisou, krabice 6

5 Roza Julien, Knoflik v lidovém kroji, Zprávy Waldesova musea knoflíků I, 1916, s. 49-59.

6 Rose Julien, Die deutschen Volkstrachten zu Beginn des 20. Jahrhunderts, Mnichov 1912.

7 Jan Koula, O spinadlech a lidovém kroji česko-slovenském, Zprávy Waldesova musea knoflíků III, 1918, s. 1-9.

8 Součástí byla i studie významného polského etnografa a zakladatele Etnografického muzea v Krakově Severina Udziela Opasky polského lidu v jižní Malé Polsce.

9 DOMLUVIL, Eduard. Knoflíky a spony moravských Valachů. Zprávy Waldesova musea knoflíků, 1918, ROČ. 3, s. 48-50. 
10 PERRY, Jane. A Collector's Guide to Peasant Silver Buttons. Lulu Press: 2007. 11 Völkerschmuck, VídeňLipsko: Martin Gerlach, 1906. 12 THIELE, Ernst-Otto, et al. Tracht und Schmuck in nordischen Raum, 2. díl. Berlín: Kabitzsch, 1938.

13 RITZ, Gislind. Alter Bäuerlicher Schmuck, Mnichov: Callwey, 1978.

14 SCHÖNWEß, Werner. Der Knopf: Frühe Scheibenknöpfe aus Metall 14.-17. Jh., Bärnau: Deutsches Knopfmuseum Bärnau, 1987.

15 JOHNOVÁ, Helena. Šperk, Bratislava: Tatran, 1986. 16 TORANOVÁ, Eva. Šperkárstvo na Slovensku. Bratislava: Pallas, 1976.

17 BALOG-HORVÁTH, Terézia. Ungarischer volkstümlicher Schmuck, Budapešt: Corvina Kiadó, 1983.

18 JOHNOVÁ, Helena. Šperk, Bratislava: Tatran, 1986, s. 13. 19 JOHNOVÁ, Helena. Šperk, Bratislava: Tatran, 1986, s. 30.
Guide to Peasant Silver Buttons ${ }^{10}$ představuje základní typologii lidových knoflíků ze stř́bra a jeho slitin podle tvarů i technologií napříč celým světem. Publikace upozorňuje na specifické znaky zdánlivě podobných knoflíků. V tomto ohledu je naprosto nedocenitelná kapitola věnovaná filigránovým knoflíkům. Snad jedinou nevýhodou je absence akceptace prolínání kulturních vlivů mezi historickým regionem Uher a Slovenskem a slovenský lidový knoflík v podstatě nezahrnuje. Druhou publikací využitelnou v obecné rovině je soubor obrazových tabulí sestavený Martinem Gerlachem. Kniha Völkerschmuck ${ }^{11}$ z roku 1906 je jednou $\mathrm{z}$ nejlepších publikací $\mathrm{k}$ tématu kovového lidového šperku napříc světovými regiony, která v detailech obsahuje i lidový knoflík.

Pro německé země jsou dobře využitelné mnohé publikace. Tracht und Schmuck in nordischen Raum ${ }^{12}$ se věnuje krojům a šperkům po jednotlivých regionech. Publikace obsahuje řadu fotografií jak samotných šperků včetně knoflíků, tak celkově krojů. Velkým přínosem jsou pasáže věnované textilnímu knoflíku, který je obecně v literatuře nedostatečně zastoupen. I když je kniha místy ideologicky dobově podmíněná, byla vydána v roce 1938, na její odborné etnografické kvalitě to nic nemění. Velmi dobře zpracovaná je publikace Gislind Ritz Alter Bäuerlicher Schmuck ${ }^{13}$, prezentující škálu exponátů z německých muzeí i mimo Bavorsko, a především v popisech exponátů uvádí i původ z menších regionů a oblastí. Specifickou starší německou produkci lidových knoflíků z období 15.-18. století, tzv. plochých nebo štítových knoflíků zachycuje útlá, ale velmi hutná publikace Wernera Schönweiße Der Knopf: Frühe Scheibenknöpfe aus Metall 14.-17. Jh $h^{14}$. Obsahuje i kvalitní obrazovou př́lohu a je užitečná při dataci a určení lokality původu.

Velmi dobrá situace je $\mathrm{v}$ případě knoflíků $\mathrm{k}$ lidovým oděvům pro regiony Slovenska a Mad'arska, respektive historických Horních a Dolních Uher. Publikace od Heleny Johnové Šperk ${ }^{15}$ a Evy Toranové Šperkárstvo na Slovensku ${ }^{16}$ přistupují ke knoflíku k jako zcela rovnocennému druhu lidového šperku vedle náhrdelníků, náušnic nebo spon. Tituly ještě doplňuje drobná knížka Terézie Balogh-Horváth Ungarischer volkstümlicher Schmuck ${ }^{17}$, která obsahuje i knoflíky z regionu Sedmihradska a zároveň nás utvrzuje v logickém prolínání kulturních vlivů. K těmto titulům bych nicméně uvedla kritickou poznámku zmíněnou již výše u publikace Jane Perry. Literatura k oblastem středního Podunají, Mad’arska a Slovenska nedostatečně reflektuje prolínání kulturních vlivi̊ a trvá na zařazení šíreji zastoupených typů knoflíků i šperků do konkrétní lokality. Proto je potřeba $\mathrm{k}$ tématu přistupovat $\mathrm{s}$ nadhledem a kritikou, zvláště tehdy, nejsou-li knoflíky součástí konkrétního specifikovaného oděvu nebo nemáme informace o nálezové situaci.

\section{Lidové knoflíky}

Knoflíky v rámci lidového oděvu tvoří velmi specifickou skupinu funkčních ozdob, které se vyznačují specifickým vzorem, tvarem a technikou zpracování, analogických k dalším ozdobám nebo regionálně specifických produktům. Jsou neoddělitelnou součástí kategorie lidového šperku, zvláště $\mathrm{v}$ případě knoflíků $\mathrm{z}$ kovu. Platí na ně i definice Heleny Johnové: „Pojmem ,lidový šperk' označujeme vše, co lid jako šperk nosil, a co se stalo typickou, neoddělitelnou součástí ludové kultury v určitém období a v určité oblasti" ${ }^{\prime 18}$. Johnová rovněž uvádí, že "knofličky od nepaměti byly kdesi na rozhraní mezi účelovým a ozdobným spínadlem" ${ }^{19}$. Na základě analýzy lze díky ustáleným identifikačním znakưm přiřadit knoflíky ke konkrétním etnikům nebo regionům, ale s přihlédnutím k možnostem různých kulturních prolínání nebo např́íklad darování v podstatě cizorodého vzoru. Komplikovanější je datace, a to vzhledem k výrazně pomalejším proměnám vzhledu i zpracování než u módní sériové výroby. Nelze se mnohdy řídit ani oděvem, na kterém jsou knoflíky našity, jelikož byly často děděny po celé generace, zvláště u náročnějších šperkařských prací. 
Lidové knoflíky bývají velmi dekorativní a na oděvu viditelné, zhotovené technikami tradičně používanými $\mathrm{v}$ daném regionu. Často se zhotovují z kovu - stř́bra nebo slitin jako mosaz či pakfong. Zastoupeny jsou i levnější kovy - cín, hliník nebo obtížně specifikovatelné slitiny. Kovy mohou být zpracovány ražbou, litím nebo technikou filigránu, která je rozšířena $\mathrm{v}$ mnoha variacích po celém světě. Obvyklé jsou kombinace technik. Povrch může být doplněn škálou ryteckých technik. Povrch, zvláště u kvalitnějších kovů, může zdobit zlacení, nielo nebo smalt, kameny ze skleněné kompozice nebo drahé kameny. Se sklem nižší jakosti nebo plastickými hmotami jako celuloid jsou kombinovány obvykle levnější kovy a toto zpracování je typické pro lacinou bižuterní produkci. Zvláštní kategorií jsou knoflíky z příze, kterým je dosud v literatuře věnováno poměrně málo pozornosti. Jsou obvykle zhotoveny $z$ dřevěného, kostěného, perletového nebo kovového základu, který je dekorován př́zí zpracovanou ovíjením matrice, vyšíváním, háčkováním a podobně. Další skupinou jsou knoflíky zhotovené ovijením drátků nebo dracounu kolem matrice $\mathrm{z}$ různých materiálů, které se často vyskytují na východoevropských krojích bohatě zdobených výšivkou dracounem. Velmi specifickou kategorií, která se rovněž může vyskytnou na lidovém oděvu, jsou knoflíky mincovní, jež jsou stejně jako filigrán celosvětově rozšíŕeným fenoménem a o jejich oblibě svědčí i produkce nepravých mincovních knoflíků.

Kde všude se lze s knoflíky na lidovém oděvu setkat? Pro svou variabilitu je možné toto spínadlo využít doslova od hlavy k patě. Nicméně se můžeme setkat s jejich využitím na kabátcích a vestách mužského oděvu párově s dírkami či očky nebo u ryze dekorativního knoflíků po obou stranách. S ryze estetickou rolí se také setkáváme na rukávech, např́klad u ženských krojů v dolním Sasku ${ }^{20}$. Ve své podstatě se tu knoflíky mění na našité aplikace, které můžeme vidět $\mathrm{v}$ různých regionech také na pásech, jak $\mathrm{v}$ oblastech Kavkazu, tak v německých regionech, i jako dekorace čepců, čelenek a klobouků. Použity mohou být jako přívěsky náhrdelníků, např́íklad u bohatě šperky zdobených ženských krojů z oblasti Fríska, dnes na území Nizozemí, Německa a na německém ostrově Föhr ${ }^{21}$. Nezř́ídka se můžeme setkat i s tím, že knoflíky mají identickou podobu s hlavicemi jehlic nebo nášivek a v rámci kroje se vzájemně doplňují nebo se jeden tvar komponentu připevňuje $\mathrm{k}$ různým mechanikám.

V muzejních sbírkách se s lidovými knoflíky setkáváme jako se součástí oděvu nebo samostatně. Hodnota uchování a prezentace $\mathrm{v}$ rámci celého oděvu spočívá v okamžité výpovědi o zpưsobu a míře užití. Knoflíky k lidovému oděvu bývají náročné na údržbu a péči, vyznačují se vysokou mírou opotřebení v podobě deformací, znečištění leštidly, druhotných, často nevhodný úprav a oprav nebo setření povrchových zušlechtění. Potenciální degradací nebo korozí materiálu jsou ohroženy výrobky z levnějších materiálů.

\section{Sbírka Waldesova muzea}

Vášeň Jindřicha Waldese pro sběratelství knoflíků a potenciál, který $\mathrm{v}$ těchto předmětech cítil, dobře vystihuje jeho vlastní citát: „knoflik, resp. spinání oděvu, je v pravém slova smyslu měř́tkem národní kultury a často dokonce i formou, $v$ níz se kultura národi jevi“"22. Waldese na knoflíku fascinovala jeho blízkost člověku, funkčnost spojená s estetikou, rozmanitost technik a materiálů. Jeho zájem byl pochopitelně i profesní, stál u zrodu jednoho z největších světových výrobců galanterie - podniku Waldes \& Co. Dobré finanční zázemí, osobní styky a zapálení pro věc daly vzniknout soukromému muzeu, které by bylo monotematickou vědeckou institucí. Na její činnost dohližžlo kuratorium, které se scházelo již od roku $1916^{23}$. Potřebná úřední povolení a oficiální činnost zahájilo muzeum o rok později. Již $\mathrm{v}$ prvních letech bylo zřejmé, že se muzeum nebude zabývat jen knoflíky, ale spínadly obecně a název se ustálil jako Waldesovo muzeum knoflíků a spínadel všech dob. Mezi lety 1916-1916 zaznamenalo muzeum
20 RITZ, Gislind. Alter Bäuerlicher Schmuck, Mnichov: Callwey, 1978, s. 67.

21 THIELE, Ernst-Otto, et al. Tracht und Schmuck in nordischen Raum, 2. díl. Berlín: Kabitzsch, 1938, s. 135.

22 Jindrich Waldes, Moje museum, Zprávy musea knoflíků I, 1916, s. 1.

23 Kuratorium bylo poradním orgánem muzea složené $z$ odborníků, průmysIníkù, úředníků nebo obchodnich partnerů Jindríicha Waldese. Jednalo se o vlivné osoby i odborníky. Mezi členy byly František A. Borovský, František X. Jiřik, Václav V. Štech, Jan Koula nebo Josef Václav Myslbek. Předsedou byl Jindřich Waldes. 
24 Podsbírka WaldesKnoflíky - rej. číslo 499 76/ 35-3353, podsbirka WaldesSpínadla a oděvní doplňky rej. čislo kulturní památky 49977/35-3353

25 Podrobně se historii sbírky Waldesova muzea věnují publikace: 1) HRUŠKOVÁ, Kateřina. Sbírka Waldes. Jablonec nad Nisou: Muzeum skla a bižuterie $v$ Jablonci nad Nisou, 2014.; 2) HRUŠKOVÁ, Kateřina. Sborník semináře $k$ 100. výročí otevření Waldesova muzea,

Jablonec nad Nisou: Muzeum skla a bižuterie $v$ Jablonci nad Nisou - Praha: Kotěrovo centrum architektury, 2018.;

3) ŠIMON, Patrik. Jindřich Waldes: sběratel umění, Praha: Eminent - Patrik Šimon, 2001.

26 Jan Hofman byl prvním reditelem muzea, a to $v$ letech 1916-1919, kdy odešel do státní správy.

27 Asijská, africká a americká spínadla byla zařazena ve Sbírce národopisné, a to bez ohledu na to, zdali se jednalo o spínadlo lidové nebo módní.28 Sbírky. Zprávy Waldesova musea knoflíků, 1918, roč. 3, s. 52.

29 AWM, krabice M114, M115, M116.

30 AWM, krabice M64, M104. 31 AWM, krabice M64, M85, M117, M118. éru intenzivní akviziční i odborné činnosti a budování stálé expozice $\mathrm{v}$ prostorách budovy $\mathrm{v}$ dnešní Moskevské ulici 262 v Praze-Vršovicích. Po skončení druhé světové války bylo muzeum zrušeno a znárodněno jako součást vršovického podniku, který byl $\mathrm{v}$ průběhu války nemorálním způsobem vykoupen a začleněn do říšské správy. Dohledem nad unikátní sbírkou bylo nově pověřeno Uměleckoprůmyslové museum v Praze. I $\mathrm{z}$ jeho intervence byla většina dochovaného sbírkového fondu v roce 1973 svěřena dočasně a od roku 1977 trvale do péče Muzea skla a bižuterie v Jablonci nad Nisou. Již od samého počátku byl soubor nově rozdělen do dvou samostatných sbírek, dnes podsbírek, s názvy WaldesKnoflíky a Waldes-spínadla a oděvní doplňky. Obě byly v roce 1999 prohlášeny za kulturní památku ${ }^{24}$ a čítají více než 6000 evidenčních jednotek. ${ }^{25}$

\section{Lidové knoflíky a spínadla ve sbírce a expozici Waldesova muzea}

Na sbírkotvornou činnost Waldesova muzea od září roku 1916 dohlížel Jan Ješek Hofman ${ }^{26}$, byly sledovány dvě základní linie. Tou první byl vývoj knoflíku a spínadla obecně ve smyslu periodizace dějin evropské kultury. U exponátů od 18. století se v podstatě jednalo o vývoj módních trendů. Druhou linií byly knoflíky a spínadla lidového oděvu, které byly soustředěny v tzv. Sbírce lidopisné, později národopisné, která zahrnovala veškeré exponáty - knoflíky, spony, přezky, háčky ke šněrovačkám, šněrovadla, pásy u části oděvu související s evropských regionem, konkrétně od Nizozemí, přes německé státy a celou střední Evropu, Balkánský poloostrov až po oblast Kavkazu. Samozřejmě se nejedná o kompletní přehled evropského lidového spínadla. Zcela chybí zastoupení států západní Evropy. ${ }^{27}$ $\mathrm{V}$ dochovaném souboru je zanedbatelné zastoupení exponátů z území dnešní České republiky. Nicméně existující reporty o nových akvizicích svědčí o tom, že by tomu tak být nemělo. Důvody pro současnou situaci mohou být dva: bud' došlo během konfiskace nebo $\mathrm{v}$ následujících letech ke ztrátě předmětů, nebo byly původně špatně určeny.

Kolekci dominují předměty $\mathrm{z}$ regionů Německa, Uher a Slovenska, přičemž první zmíněný celek je vůbec největší. Další regiony jsou zastoupeny pouze $\mathrm{v}$ řádech kusů a budou zmíněny $\mathrm{v}$ závěru rozboru souboru. Podle dochovaných přehledů o nových akvizicích i účtech za nákupy byly předměty do této kolekce pořizovány méně formou darů a ve většině př́ipadů formou nákupů. Velkým koordinátorem akvizic z německého regionu byl Eduard Merzinger, Waldesův obchodní partner a ředitel drážd’anské pobočky Waldes \& Co. Realizoval jednak nákupy, které zvláště po vzniku samostatného Československa byly výhodně řešeny přes továrnu v Drážd’anech. Sám Merzinger se zasloužil i o řadů darů. Zřejmě i z tohoto důvodu jsou německé země tak dobře zastoupené. Nákupy se realizovaly také ve Vídni. V roce 1918 získalo muzeum exponáty $\mathrm{z}$ řady aukcí, $\mathrm{z}$ aukčního domu Helbing, H. \& Hirsch, J. v Mnichově, z Umělecké a aukční síně Rudolf Weinert v Praze, nebo z aukce v Ernst Museu v Budapešti a samozřejmě ve vídeňském Dorotheu ${ }^{28}$. Na aukcích muzeum zastupoval bud ředitel Hofman nebo pověření a spolehliví spolupracovníci akvizitéři jako Leopoldina Auzingerová z Berlína ${ }^{29}$ nebo Julius Sofer ${ }^{30}$ ve Vídni. Stejně tak s muzeem spolupracoval Ernst Sachsenhauser z německého Mnichova, který kromě akvizic zajištoval získávání obrazového materiálu $\mathrm{z}$ německého regionu $^{31}$. Veškeré akvizice byly postupně evidovány, bohužel lístková kartotéka se nezachovala a na provedenou evidenci dnes odkazují pouze dochovaná původní evidenční čísla na předmětech. Po novém upořádání souboru, které bylo zahájeno v roce 1973, došlo k opětovnému zpracování předmětů, jež je ale $\mathrm{v}$ řadě ohledů nedostatečně provedené, a zvláště citelný je tento nedostatek u lidového knoflíku. I proto je $\mathrm{v}$ současnosti soubor zpracováván opětovně.

Vedle budování sbírky trojrozměrných předmětů si členové kuratoria stanovili 
jako jeden z cílů vytvoření Krojového archivu, protože důraz byl kladen i na to, aby spínadla mohla být studována $\mathrm{v}$ kontextu celého oděvu. Dochovaný materiál obsahuje více než tisíc fotografií př́slušníků různých etnik ve slavnostních krojích i při běžných činnostech. Specifickou skupinou jsou fotografie muzejních expozic a exponátů (Obr. 4), které si Waldesovo muzeum nechávalo pořizovat na objednávku. Spolupracovalo např́ílad s Národopisným museem českoslovanským v Praze, s Královským etnologickým muzeem v Berlíně, s Bavorským národním muzeem v Mnichově, ale také s muzei na Balkáně. Stejně jako exponáty byly zakupovány i cykly fotografií. $V$ řadě př́ípadů jsou fotografie na rubové straně ručně popsány. Obvykle se jedná o informaci o obsahu fotografie nebo jméno fotografa či ateliéru, případně obojí. Některé fotografie mají pořadová čísla, ale jejich význam je předmětem dalšího zkoumání. Mezi velmi zajímavé kolekce fotografií patří cyklus Obyvatelstvo severního Nëmecka na fotografiích etnografky Rose Julien a dokumentace muzeí na Balkánském poloostrově, především expozice Etnologického muzea v Sarajevu. Druhým typem materiálu jsou barevné grafiky, většinou cykly nebo části cyklů zobrazující opět různá etnika $\mathrm{v}$ modelových krojích. Nutno podotknout, že zvláště fotografie obyvatelstva jsou materiálem ilustračním, využitelným spíše pro studium krojů jako takových, knoflíky nejsou ve většině případů $\mathrm{v}$ dostatečném rozlišení, ale v kombinaci s trojrozměrným materiálem původní záměr funguje. To vše měla ještě doplňovat knihovna $s$ tematickou literaturou, periodiky a tzv. Odborných archiv, jehož jedna část byla historická a součástí byly i výpisky z významných archivních pramenů. Druhá část byla technologická, orientovaná především na proces zhotovování knoflíků. Tyto další materiály se bohužel zachovaly minimálně.

Pokud bychom chtěli i pouze na základě dochovaného sbírkového fondu a obrazových materiálů hodnotit, jak se podařilo naplnit původní záměr muzea, tedy

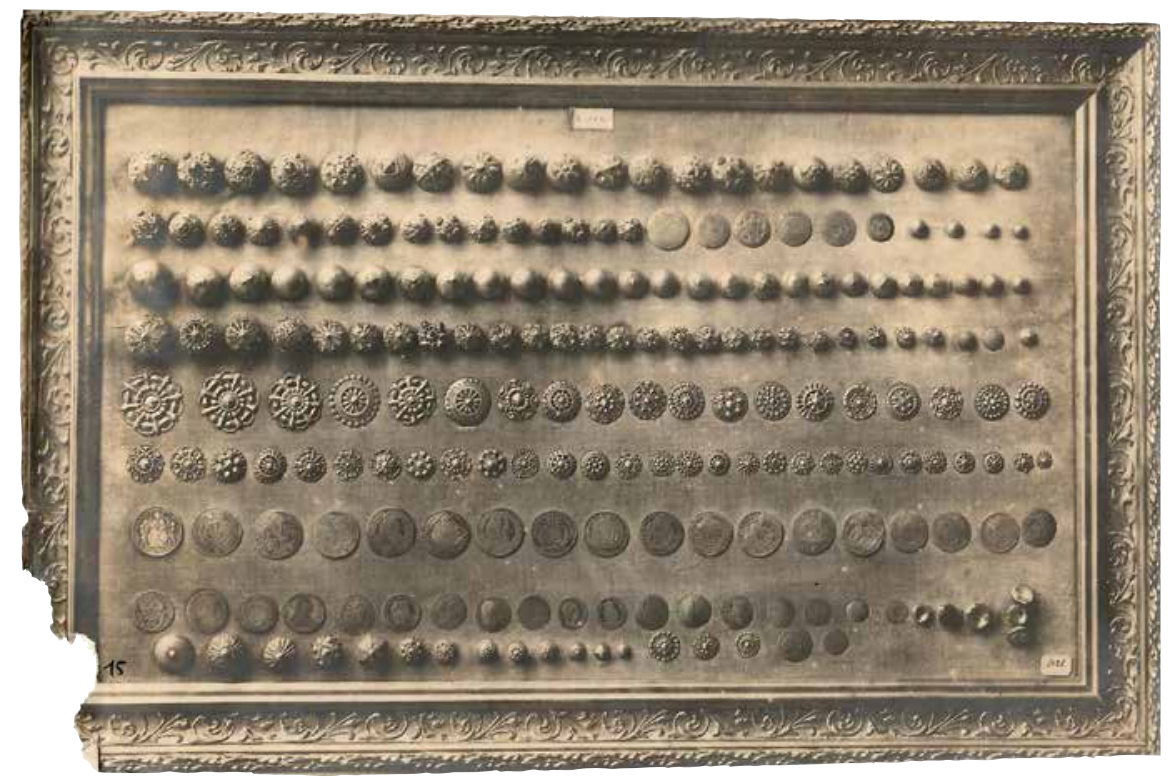

zajistit dostatek reprezentativního studijního materiálu $\mathrm{k}$ tématu vybraných skupin evropských lidových knoflíků a spínadel obecně, je nutné uvést, že žádné z témat, které ve sbírce rezonují, není tak dobře zastoupeno a zdokumentováno jako právě toto.

Část expozice věnovaná lidovým spínadlům byla skutečně reprezentativní. V době otevření muzea na toto téma odkazovala již Vstupní síň, obsahující soubor obrazů $\mathrm{k}$ dějinám krojů a spínadel. Pravděpodobně až v průběhu 20. let došlo $\mathrm{k}$ úpravě sálu na technologickou úvodní expozici. Lidová spínadla byla obsažena na několika místech expozice. Ve třetí síni byla vystavena kolekce spon $\mathrm{k}$ uherským a polským krojům z 19. století. Pátá síň byla lidovému spínadlu věnována celá. V rámci stálé expozice byly $\mathrm{v}$ jeden celek spojeny Sbirky lidopisná a národopisná, která se věnovala mimoevropským lokalitám. Pozdější fotografie, které jsou dnes v archivu Národního technického muzea ukazují, že národopisná expozice byla postupně rozšířena do přiléhajícího prostoru a blízké předsíně. $\mathrm{V}$ expozici byly sbírkové předměty instalovány v dekorativních aranžmá na tematických tablech, která prezentovala jednotlivé regiony. U etnografických sbírek byly pohromadě instalovány všechny typy spínadel. Na přelomu let 1919 a 1920 byl jako podklad zvolen karton potažený plstí v barvě univerzální šedi a adjustace předmětů umožnila snadné sejmutí pro badatelské účely. Bohužel se z Lidopisné sbírky dochovalo v kompletním stavu pouze jedno kompletní tablo.
Obr. 3. Ukázka z Archivu krojového, Výstavní tablo s lidovými knofliky z německých regionů, fotograf: Anton Grainer, Traunstein, původní č. i. 15, Archiv Waldesova Muzea, Muzeum skla a bižuterie $v$ Jablonci nad Nisou, krabice 6 
Rozbor souboru lidových knoflíků v podsbírce Sbírka Waldes-Knoflíky

Ze všech tematických oblastí, na které se Waldesovo muzeum při tvorbě své sbírky zaměřilo, bylo téma lidového knoflíku a spínadel obecně tím nejvíce propracovaným a z hlediska objemu a rozsahu dochovaného materiálu. Lze tedy objektivně říci, že v této byl oblasti cíl úspěšně plněn, ovšem ne splněn. Kolekce knoflíků, která z této aktivity vznikla, je ve sbírce vůbec tou nejpočetnější. Čítá více než čtyři sta padesát kusů knoflíků, tedy objemově zhruba deset procent podsbírky Sbírka Waldes-Knoflíky. Obsahuje solitéry, páry i sady, které jsou ilustrativně doplněny několika částmi oděvu a doplňky s knoflíky z paralelní podsbírky Sbírka WaldesSpínadla a oděvní doplňky, jež nám ilustrují použití knoflíků $\mathrm{v}$ tzv. přirozeném prostředí. Konkrétně se jedná se o tři kusy pásů dekorovaných knoflíky, pět kazajek a čtyři vesty, které jsou níže přiřazeny ke konkrétním celkům. $\mathrm{Z}$ pohledu regionálního začlenění soubor obsahuje knoflíky z Nizozemí, Německa, Rakouska, Čech (Chebska), Mad’arska, resp. Dolních Uher zastoupených především regionem Sedmihradska, Slovenska, resp. Horních Uher, Dalmácie, Makedonie a Ruska, především oblasti Kavkazu. Z hlediska datace se jedná o předměty z 19 . století, méně pak z přelomu 19. a 20. století a výjimečně z meziválečného období. Kolekce německých štítových knoflíků rozšiřruje dataci souboru až do 17. století. Část knoflíků, přibližně 30 procent, se nepodařilo přesněji zařadit, nicméně typově zapadají do regionů střední a východní Evropy. Z pohledu způsobu zpracovávání dle Johnové jsou ve sbírce zastoupeny řemeslné zlatnické práce a práce lidových samouků, továrenské sériové bižuterní výrobky zde zastoupené nejsou ${ }^{32}$. $V$ př́padě textilních knoflíků nebo některých lisovaných knoflíků z druhé poloviny 19. století, např. švábských Glanzgeschnittenen, se jedná o malosériovou domácí nebo menší dílenskou výrobu. $\mathrm{Z}$ hlediska materiálů převládají výrobky ze stř́ibra, $v$ některých případech zlaceného, obecných kovů a jejich slitin. Výraznou skupinou jsou knoflíky mincovní, které byly v lidovém prostředí rovněž oblíbené. Méně početnou skupinou jsou textilní knoflíky zhotovené z příze, knoflíky z dracounu nebo zlaceného drátku. $V$ rámci následujícího rozboru je soubor členěn geograficky dle modelu využívaného Waldesovým muzeem.

Nizozemí je zastoupeno souborem jedenácti knoflíků. Deset z nich jsou vysoce kvalitní stříbrné filigránové knoflíky, kterým se přezdívá „nizozemská ostružina“ nebo jednoduše "Zeeuwse“, což znamená „nizozemský" " Tyto stř́ibrné filigránové knoflíky jsou tvarem a provedením specifické a dobře identifikovatelné. Ve sbírce se vyskytují $\mathrm{v}$ různých velikostech průměru 10 až $26 \mathrm{~mm}$. Zastoupeny jsou dvě základní varianty, kdy vrchní ozdobný kroužek mezi horním spirálovým kroužkem a řadou spodních spirálových kroužků tvoří bud' řada oddělených spirálek komponovaných kolem knoflíku do kruhu nebo kroužek ze splétaných točených drátků (Obr. 5-1). Druhým zastoupeným typem nizozemských knoflíků je litý osmihranný knoflík typický pro oblast Drenthe (Obr. 6-1), který se vyskytuje pouze v jednom exempláŕi. Zdobí ho motiv jezdce na koni. Tento typ motivů se vyskytuje již na starších knoflících z 18. století, nicméně podle způsobu označení a zpracování zadní strany se jedná o mladší nápodobu staršího vzoru vyrobenou v 19. století.

Neobsáhlejší, a co do škály variant nepestřejší kolekcí je ta související s regiony Némecka. Platí to tak jak o samotných knoflících, tak o dochovaném obrazovém materiálu. Knoflíky z různých německých regionů jsou velmi zajímavým studijním tématem, protože staré tradiční vzory slouží jako předloha pro moderní výrobu k novodobým krojům a lze tak sledovat vývoj určitých typů knoflíků a samozřejmě šperku. I když to není předmětem této studie, je vhodné zmínit, že přenos tradičních a dlouho oblíbených vzorů lze pozorovat $\mathrm{u}$ některý velkosériově vyráběných knoflíků v rámci jabloneckého bižuterního průmyslu, a to na materiálech sklo a kov již na konci 19. století. Vývojové linky 

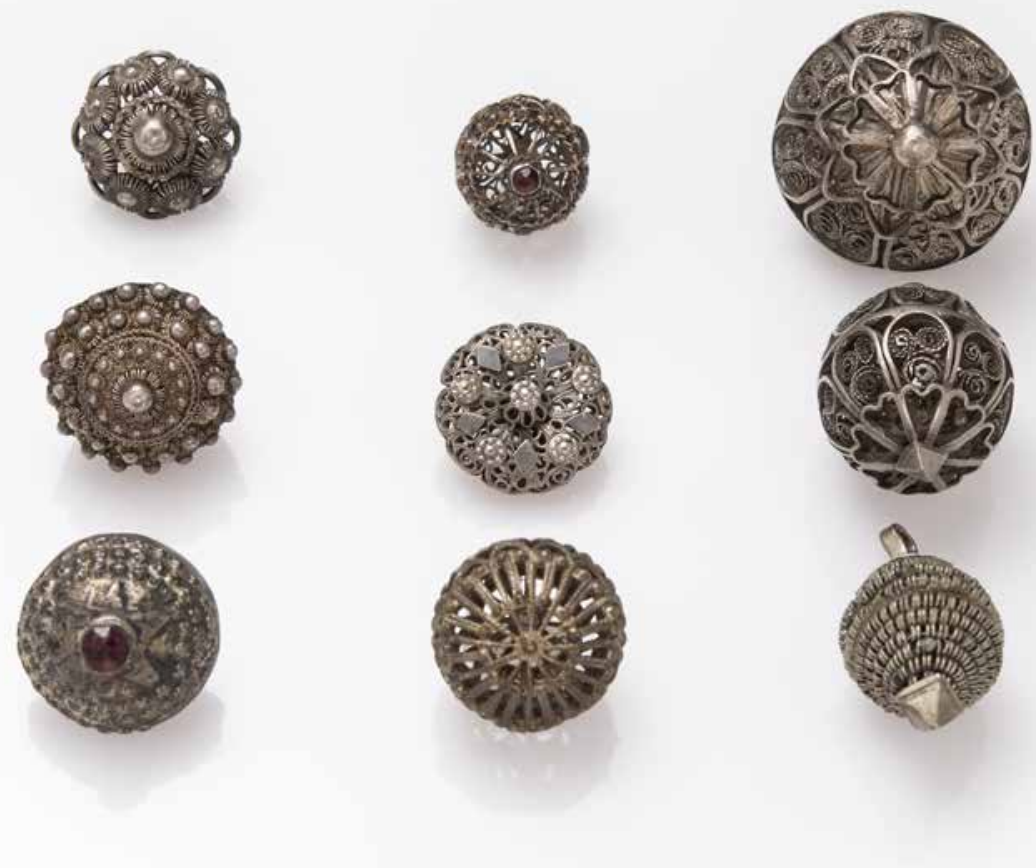

Obr. 5. (číslování zleva po řadách): KNOFLÍKY 5-1 WK1066, „nizozemská ostružinal Zeeuwse", střibro, Nizozemí, 1800-1900, Ø 24 mm, v 23 m; 5-2 WK1044, stříbro, sklo, puncováno (jednorožec), Schwäbisch Gmünd, 1800-1900, Ø 13 mm, v 28mm; 5-3 WK1103, stříbro, Dunajské Švábsko? nebo Slovensko?, 1800-1900, Ø $38 \mathrm{~mm}$, v 42 mm; 5-4 WK1062, stříbro, Severní Německo, Hamburská oblast - Altesland, 1800-1900, Ø $26 \mathrm{~mm}$, v $31 \mathrm{~mm}$; 5-5 WK03415, obecný kov - ražený nepravý filigrán, rolnička uvnitř, Jižní Německo, 1850-1920, Ø $24 \mathrm{~mm}$ v 6 mm; 5-6 WK01038, stříbrný filigrán, puncováno, Slovenskol Mad'arsko, 1800-1900, Ø $37 \mathrm{~mm}, v 40 \mathrm{~mm}$; 5-7 WK1069, obecný kov, lisovaná nápodoba filigránu, sklo, Severní Německo, Altesland, 1800-1900, Ø $26 \mathrm{~mm}$, v 25 mm; 5-8 WK1058, obecný kov, ražená nepravý filigrán, Rusko, 1800-1850, Ø $25 \mathrm{~mm}$, v 27 mm; 5-9 WK1049, stríbro, Dalmácie, 1850-1920, Ø $21 \mathrm{~mm}$, v $44 \mathrm{~mm}$; Sbírka Muzea skla a bižuterie v Jablonci nad Nisou, podsbirka Sbírka Waldes-Knoflíky, foto: Aleš Kosina, 2021

Obr. 6. (číslování zleva): KNOFLÍKY 6-1 WK3390, stříbro lité, Nizozemí - Drenthe, 18001900, Ø $27 \mathrm{~mm}$, v $6 \mathrm{~mm}$; 6-2 WK2990, stříbro ražené, patinováno, Jižní Německo, 18001900, Ø $29 \mathrm{~mm}$, v $9 \mathrm{~mm}$; Sbírka Muzea skla a bižuterie v Jablonci nad Nisou, podsbírka Sbírka Waldes-Knoflíky, foto: Aleš Kosina, 2021 


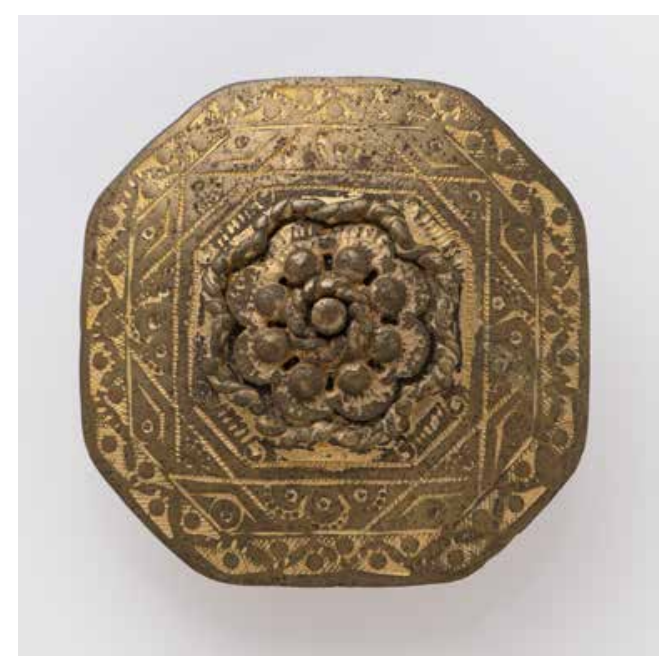

Obr. 7. KNOFLÍK "Huasnoantoutara" WK1055c, mosaz zlacená, litá, rytý dekor, Chebsko, 1800-1900, Ø59cm,

v $23 \mathrm{~mm}$; Sbírka Muzea skla a bižuterie $v$ Jablonci nad Nisou, podsbírka Sbírka

Waldes-Knoflíky, foto: Aleš Kosina, 20. 4. 2021

Obr. 9. ŠTÍTOVÉ KNOFLÍKY WK3020, mosaz, rytý dekor, 1700-1800, Ø $32 \mathrm{~mm}$, $v 8,6 \mathrm{~mm}$;

WK637, postríbřená a zatíraná mosaz, rytý a trambulírovaný dekor, 1700-1800,

$\varnothing 35 \mathrm{~mm}$, v $12 \mathrm{~mm}$; WK3069, postříbrená mosaz, 1750-1850, Ø $30 \mathrm{~mm}$,

v 9,5 mm; Sbírka Muzea skla a bižuterie $v$ Jablonci nad Nisou, podsbírka Sbírka Waldes-Knoflíky, foto: Aleš Kosina, 2021

33 Huasnoantoutara, Wikipedia [cit. 31.3.2021]. Dostupné z: https://de.wikipedia.org/wiki/Huasnoantoutara

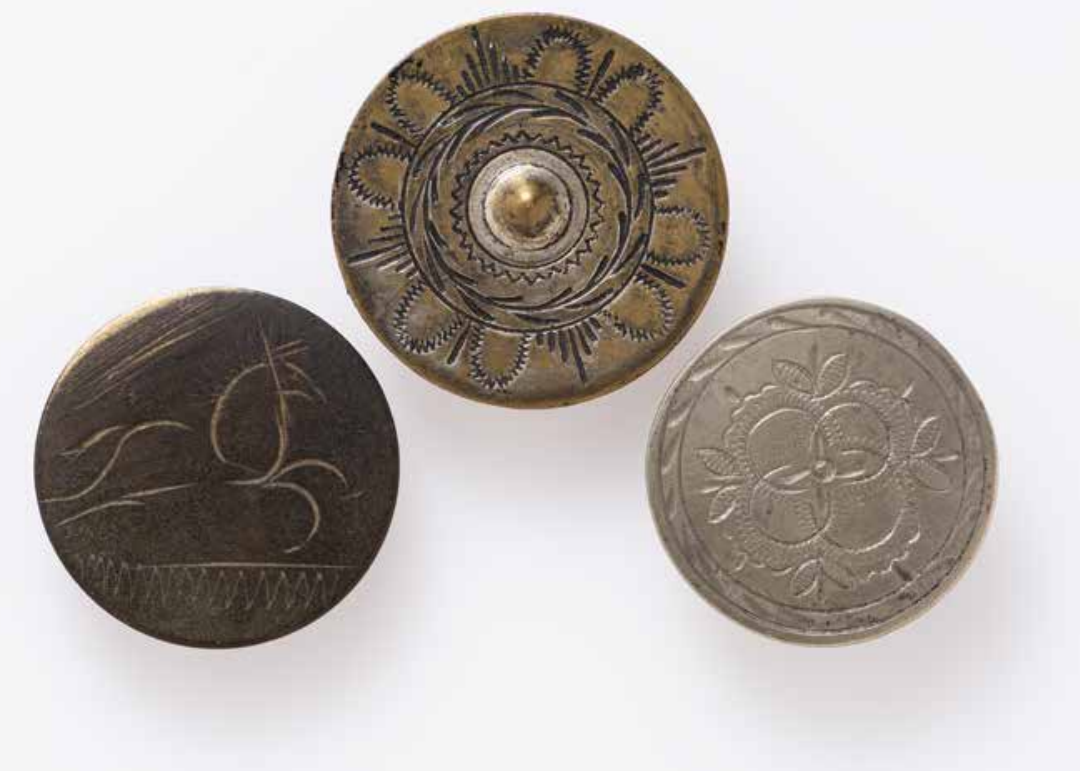

k současnosti lze sledovat $\mathrm{u}$ sortimentu pro bavorský trh, především v kovové produkci.

Oblast severního Německa kolem Hamburku, tzv. Altes Land je zastoupena jednak stříbrnými, na dekor bohatými filigránovými knoflíky (Obr. 5-4) a jednak střídmějšími lisovanými knoflíky (Obr. 5-7). V obou případech se vyskytují na ženském oděvu. Filigránové knoflíky $\mathrm{z}$ této oblasti jsou v porovnání s ostatními německými regiony i Nizozemím velmi bohaté a zároveň jemné zpracováním ve vrchní polovině, spodní strana mívá podobu jednoduché lité polokoule. Řady spirálových kroužků jsou doplněné i několika řadami pletených stáčených drátků, které tvoří efekt kladených řetízků. Knoflíky navíc dosahují poměrně velkých rozměrů. $\mathrm{V}$ rámci oděvu nalézají využití i jako ozdoba dekoltu, přívěsky k náhrdelníkům nebo ozdoba tkanic šněrovaček. Lisované knoflíky ve své základní kompozici napodobují filigrán. Vrchol knoflíku je zdoben hvězdicí, typickým motivem pro tuto oblast. Doplněn může být skleněným nebo přírodním kamenem, ve sledovaném souboru se jedná právě o skleněné kameny horší jakosti.

Typickým knoflíkem mužského oděvu pohraničního regionu Chebska/Egerland jsou masivní osmihranné knoflíky známé v našem prostředí jako tzv. chebské knoflíky (Obr. 7). Jedná se v podstatě o jedinou kolekci spadající na české území, ale spojenou s německým kulturním prostředím. Reprezentativní kolekce čítá třináct kusů o průměrech 38 až $56 \mathrm{~mm}$ s rozmanitým zpracováním dekoru. Tento typ knoflíku nazývaný Hosenknopf, lidově Hosenantuer nebo Huasnoantoutara ${ }^{33}$, se používá pro spojení typického pásu, v podstatě kožených šlí, a kalhot. Také zdobí spojovací část šlí na přední straně mužova trupu - zde je knoflík pouze dekorací, nikoliv spínadlem, bývá masivnější a dekorativnější než ostatní "funkčni" kusy. Knoflíky nejsou našívány, ale fungují na principu roubíku. Tvoří je v podstatě dva knoflíky různých velikostí spojené válcem či válečkem, knoflík na rubové straně je menší a kruhový. Lícová strana je výrazně dekorována rytinou nebo

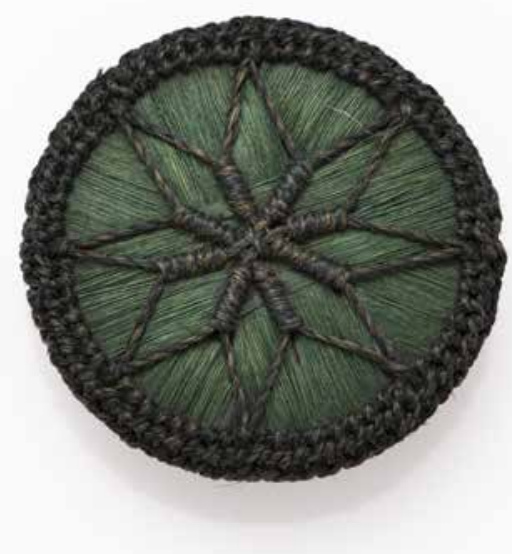

Obr. 8. KNOFLíK WK1628b, textilní vlákno, dřevo, Krušnohoří, 1850-1900, Ø39 mm; Sbírka Muzea skla a bižuterie v Jablonci nad Nisou, podsbírka Sbírka WaldesKnofliky, foto: Aleš Kosina, 2021 

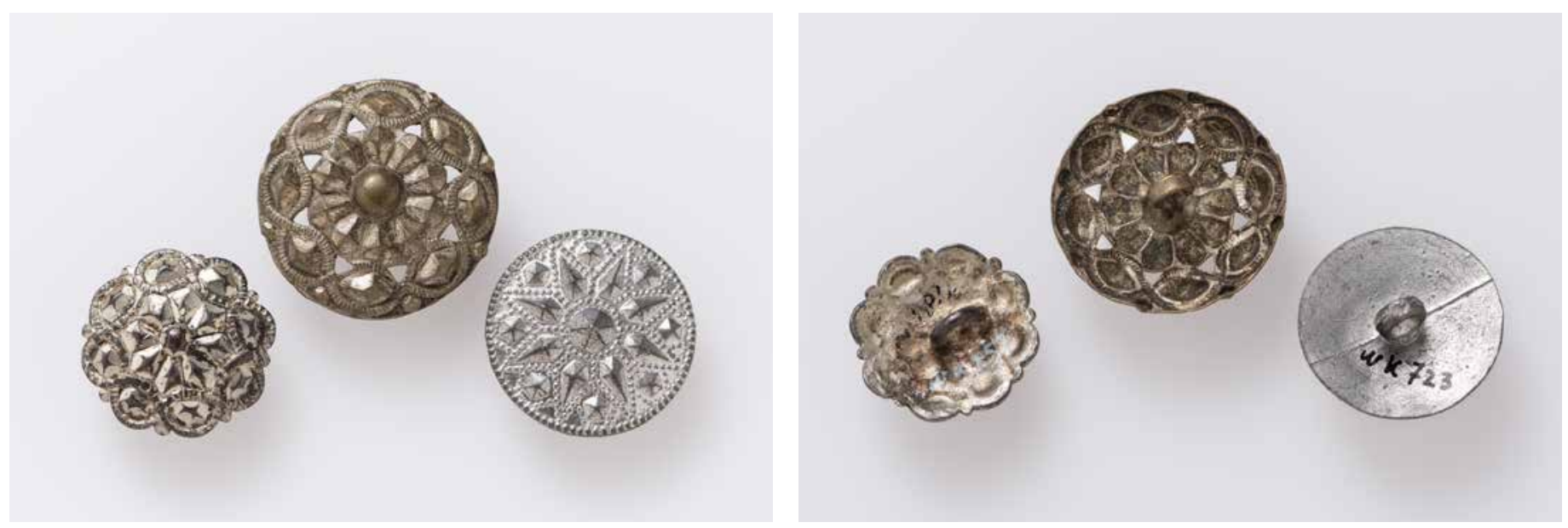

cizelováním, střed je vypouklý s hrbolem nebo rozetou uprostřed, kolem se může nacházet stáčený drát. Knoflíky jsou z mosazi se zlaceným povrchem a vyznačují se masivním provedením. Kolekci doplňuje vzorem analogický běžný plochý knoflík. Další poměrně bohatý celek tvoří knoflíky zhotovené z barevné příze čítající tři desítky kusů. Jedná se o zlidovělé knoflíky jinak vyráběné jako galanterní zboží v rámci domácí práce. Nejčastěji se jedná o knoflík s dřevěným základem, jehož povrch je zcela pokryt textilním vláknem. Výtvarné zpracování je u těchto knoflíků většinou geometrické, monochromatické, které pracuje s vrstvením a překrýváním nití nebo $\mathrm{v}$ jednoduché barevnosti. Zastoupeny jsou i florální motivy zhotovené jak výšivkou, tak háčkováním. Typické jsou pro oblast Krušnohoříi ${ }^{34}$. (Obr. 8)

Velmi specifickou skupinou jsou tzv. štítové knoflíky "Scheibenknöpfe“ (Obr. 9), se kterými se lze setkat naprríč různými oblastmi Německa. Dochovaná kolekce čítá patnáct kusů a prezentuje průřez všemi základními motivy a technikami zpracování z období 17 . až 19. století. Mezi dekory nalezneme koně, jednoduché klikatky, různé kompozice florálních motivů vycházejících z barokních vzorů až po rozety se středovým hrbolem, které jsou typické pro Švábsko. Kolekce obsahuje i prořezávané knoflíky ve tvaru jednoduchých i točených hvězdic, vyskytujících se od severnějších regionů Evropy po jih Německa. Kolekci z Waldesova muzea zmiňuje jako významný soubor i publikace Německého muzea knoflíků v Bärnau ${ }^{35}$ „Der Knopf: Frühe Scheibenknöpfe aus Metall ${ }^{\text {"36. }}$. Pro výrobu těchto knoflíků byla nejčastěji využívána mosaz nebo slitiny mědi, povrch může být postř́ibřen, reliéf může být zvýrazněn patinací. Dekor je rytý a pro jeho zhotovení mohli rytci využít širokou škálu nástrojů a dílčích postupů. Kolekci knoflíků doplňuje masivní kožený mužský pás zdobený právě štítovými knoflíky, z nichž bohužel některé byly částečně ulomeny. ${ }^{37}$

Jižní Německo reprezentuje hned několik velmi charakteristických druhů lidových knoflíků. Tím první jsou tzv. "Glanzgeschnittenen", knoflíky typické pro region kolem města Schwäbisch Gmünd. (Obr. 10a+10b) Jsou kruhového tvaru v dekoru pravidelné geometricky komponované rozety, jejichž vzhled vychází z ocelového šperku. První se objevují v 18. století, kdy byly zhotovovány stříbrné knoflíky jako módní záležitost imitující právě knoflíky z ocelových šatonư ${ }^{38}$. Jedná se o ukázku zlidovění původně módního vzoru a následné rozpracování výchozího motivu. Velkou oblibu si získaly mezi lety 1810-1830 u venkovského obyvatelstva alpských oblastí, regionů jižního Německa až Rakouska, především v oblasti Salzburska, kde byly zhotovovány z litého stříbra. Jedná se o typický mužský knoflík, který se nosil na tmavém kabá$t^{39}$. Postupně se zhotovovaly i ražením ze stř́ibrného plechu nebo dokonce $\mathrm{z}$ mincí. Vznikala také levnější produkce z obecných kovů. Na konci 19. století se objevují i výrobky z hliníku. Ve Sbírce WaldesKnoflíky se jich vyskytuje více než třicet a zastupují všechny výše uvedené techniky používané napřič 19 . stoletím, vyjma druhotné ražby z mince. Kolekce zahrnuje i sady a velmi neobvyklá je varianta se zlaceným povrchem. Široká je i škála vzorů a velikostí. Právě tyto knoflíky jsou typickou inspirací produkce skleněných knoflíků na Jablonecku. Z litého kovu se jejich nápodoby vyrábějí i v současnosti, nejen na Jablonecku. Kolekci solitérů
Obr. 10a - líc $110 b-r u b$. KNOFLÍKY:

"Glanzgeschnittenen" WK352, slitina střibra, lití, Schwäbish Gmünd, 18301850, Ø $25 \mathrm{~mm}$;

WK2453, slitina stríbra, raženo, Schwäbish Gmünd, 1850-1900, Ø $39 \mathrm{~mm}$; WK723, hliník, lití, Schwäbish Gmünd, 1830-1850,

$\emptyset 25 \mathrm{~mm}$; Sbírka Muzea skla a bižuterie $v$ Jablonci nad Nisou, podsbírka Sbírka Waldes-Knoflíky, foto: Aleš Kosina, 2021

34 LEHANN, Sigfried. Sinnbild an Tracht und Schmuck. In: THIELE, Ernst-Otto, et al. Tracht und Schmuck in nordischen Raum, 2. díl. Berlín: Kabitzsch, 1938, s. 193.

35 Deutsches Knofpmuseum Bärnau.

36 SCHÖNWEB, Werner. Der Knopf: Frühe Scheibenknöpfe aus Metall 14.-17. Jh., Bärnau: Deutsches Knopfmuseum Bärnau, 1987, s. 4.

37 Pás mužský, W2131b. 38 PERRY, Jane. A Collector's Guide to Peasant Silver

Buttons. Lulu Press: 2007, s. 52. 39 Ibidem, s. 52. 

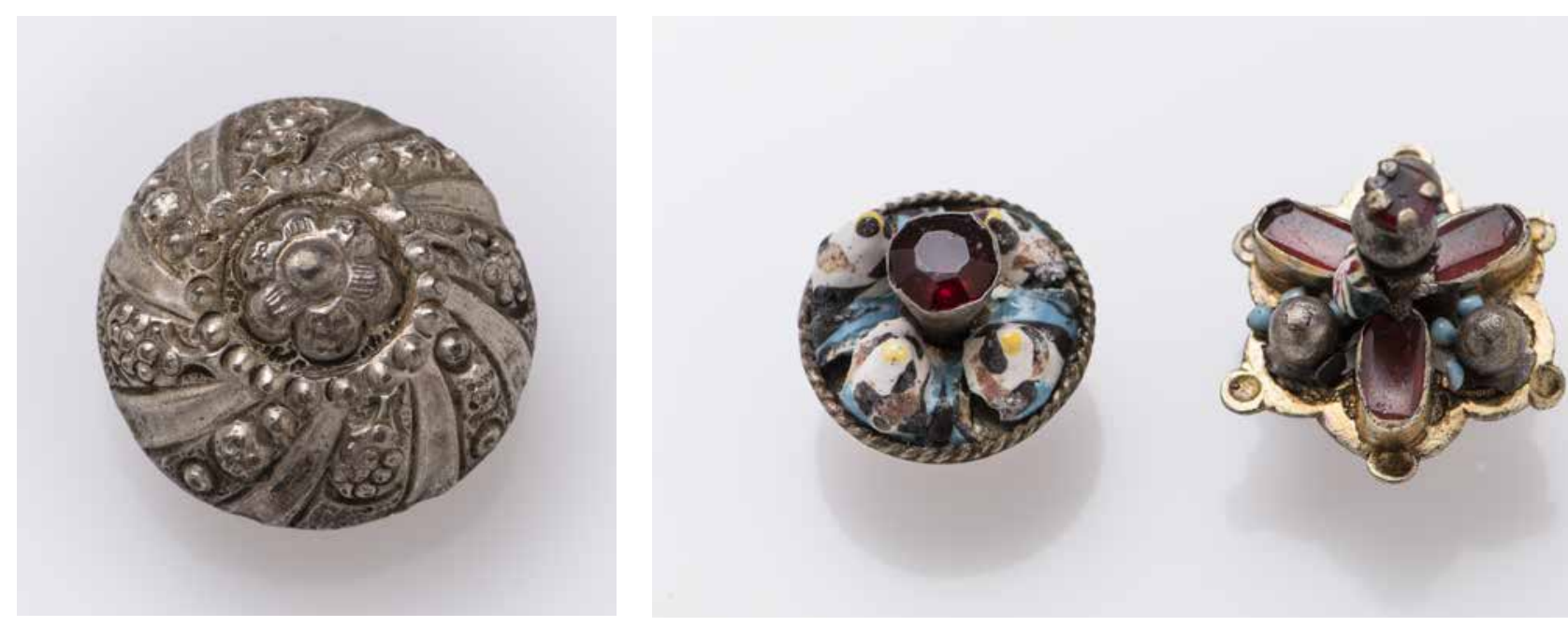

Obr. 11. KNOFLÍK WK3408, obecný kov litý, Jižní Německo/Rakousko, Salzbursko, 1800-1900, Ø 33, v 22 mm; Sbírka Muzea skla a bižuterie $v$ Jablonci nad Nisou, podsbírka Sbírka

Waldes-Knoflíky, foto: Aleš Kosina, 20. 4. 2021

Obr. 12: KNOFLÍKY zleva WK39, střibro lité a ražené, filigránový drátek, skleněná kompozice, smalt, Sedmihradsko, 1800-1900, $\varnothing 21 \mathrm{~mm}, \mathrm{v} 19 \mathrm{~mm}$; WK57, stříbro lité a zlacené, skleněná kompozice, smalt, Sedmihradsko, 1800-1900, $\emptyset 27 \mathrm{~mm}, v 28 \mathrm{~mm}$ Sbírka Muzea skla a bižuterie $v$ Jablonci nad Nisou, podsbirka Sbirka WaldesKnoflíky, foto: Aleš Kosina, 2021

40 Vesta pánská, W 2158 a. 41 PERRY, Jane. A Collector's Guide to Peasant Silver Buttons. Lulu Press: 2007, s. 70. 42 Této velmi specifické skupině se věnuje text: DREND, Misch. Der Schmuck der Siebenbürger Sachsen. In: THIELE, Ernst-Otto, et al. Tracht und Schmuck in nordischen Raum, 2. díl. Berlín: Kabitzsch, 1938, s. 166-184.

43 Sedmihradští Sasové, Wikipedia [cit. 25.3.2021].

Dostupné z: https:// cs.wikipedia.org/wikil Sedmihrad\% C5\%A1t\% C3 $\% A D$ Sasov $\%$ C3\%A9 44 W 2138/4, Soubor dřevěných figur $v$ bavorském lidovém oděvu. doplňuje vesta z červené hedvábné látky se zlatými kvítky, která je zdobená dvěma řadami ražených prolamovaných knoflíků tohoto typu, které lze datovat do poloviny 19. století $^{40}$

Z jižního Německa, z oblasti Alp pochází osmihranný knoflík s nepravidelným florálním motivem (Obr. 6-2). Je litý ze stříbra a rytý dekor je zvýrazněn zatřením černou barvou, jedná se o novější nápodobu staršího vzoru z první poloviny 19. století, pravděpodobně z 20. let 20. století. Tyto vzory byly oblíbeným doplňkem moderních krojů i v polovině 20. stoletít ${ }^{41}$.

Oblast jižního Německa a rakouského Salcburska zastupuje soubor litých dutých knoflíků, které mají tvar vypouklé rozety tvořené květy a drobnými půlkulovitými výstupky na zpơsob nápodoby filigránu. (Obr. 11) Knoflíky zhotovované ze stř́bra

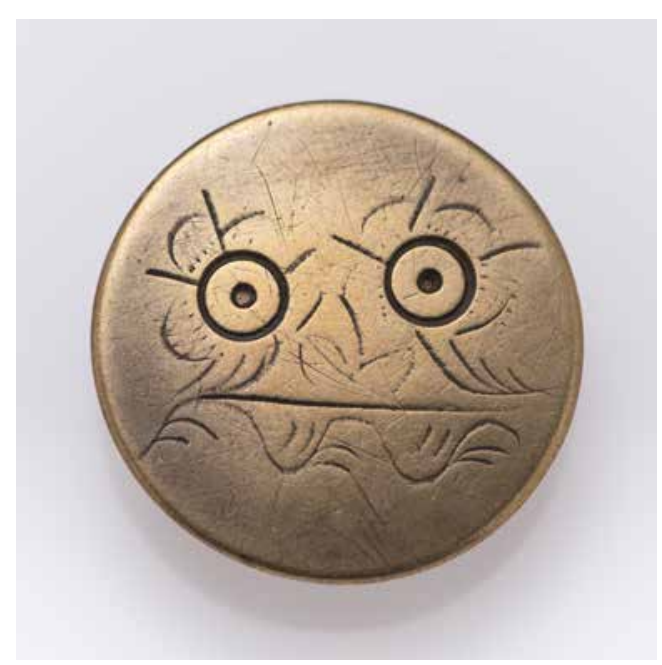

Obr. 13. KNOFLÍK WK2632, mosaz ražená, 1800-1900, Slovensko, Ø $29 \mathrm{~mm}$, v 9 mm; Sbírka Muzea skla a bižuterie v Jablonci nad Nisou, podsbirka Sbirka WaldesKnoflíky, foto: Aleš Kosina, 2021 nebo mosazi mohou být vysoké i 2 centimetry. Specifickým tvarem jsou vysoké knoflíky se základnou o průměru $1 \mathrm{~cm}$. Všechny pocházejí z období 19. a počátku 20. století. Jedná se o typ, který je vyráběn i v současnosti. Vedle zjednodušeného designu se moderní produkce vyznačuje i označením ryzosti stříbra 800 .

Jižní Německo je také bohaté na stř́ibrnou filigránovou produkci. $V$ některých případech může být takový knoflík doplněn sklem červené (Obr. 5-2) nebo modré barvy či granátkem. Filigrán byl kvưli své vysoké ceně často napodobován levnějšími technikami. Jednou z možností je ražený nepravý filigrán, který na rozdíl od litých knoflíků lépe imituje vzdušnost a jemnost. Takové knoflíky mohou být doplněny drobnými kosočtverci pro zvýšení efektu lesku, uvnitř knoflíku pak mohla být vložena malá rolnička (Obr. 5-5). Knoflíky, jejichž vzhled patří k tématu kulturní výměny a lze se s nimi setkat v různých regionech, jsou atypické knoflíky zdobené smaltem, jejichž zpracování výrazně připomíná nákladné lidové knoflíky ze Sedmihradska a v podstatě ze zdejší tradice vychází. (Obr. 12-1) Tyto knoflíky jsou tradiční u kroje tzv. sedmihradských Sasů ${ }^{42}$ a vyskytovaly se na jejich krojích i po přesídlení této etnické skupiny do Rakouska, Německa i do zámoří. Odchod této menšiny ze Sedmihradska začal po přerozdělení Evropy po první světové válce, kdy toto území připadlo Rumunsku a výrazně se počty jejich členů snížily po druhé světové válce ${ }^{43}$.

Ke kolekci lidových knoflíků z německého prostředí patří i další ilustrační předměty. Např́klad dřevěná figura ${ }^{44}$ muže vysoká $36 \mathrm{~cm}$ oděná $\mathrm{v}$ lidovém kroji $\mathrm{z}$ bavorské oblasti. Jeho kazajka a vesta je doplněná 


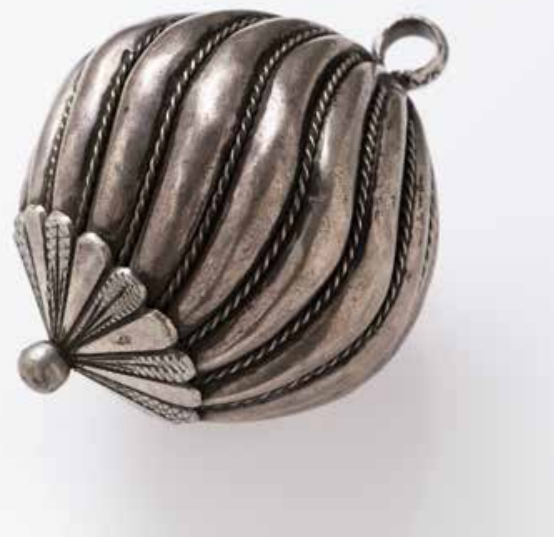

tzv. štítovými knoflíky. Náleží k dalším třem krojovaným figurám, ženy a dvou mužů - hudebníků.

Další hojně zastoupenou oblastí je Slovensko, které reprezentuje poměrně široká škála knoflíků většinou šperkařského provedení. S řadou dekorů, které jsou např́klad Helenou Johnovou řazené na Slovensko, se můžeme setkat v dalších titulech od Terézie Balogh-Horváth nebo od Jane Perry setkat $\mathrm{v}$ podobě reprezentantů mad'arského, resp. dolnouherského lidového knoflíku. Je skutečně nutné si připustit prolínání kulturních vlivů, zvláště u takto historicky propojených zemí a oblastí, a neustrnout na potřebě předměty přiřazovat jen a pouze ke konkrétní lokalitě, ale spíše ke kulturnímu okruhu. Jednoduché ploché knoflíky s rytecky zpracovaným dekorem květu, které jsou typické pro oblast Oravy, zastupuje bohužel značně opotřebený knoflík z mosazi (Obr. 13), zařazený pouze $\mathrm{v}$ tomto jednom exempláři. Lité knoflíky dále zastupují vřetenovité trojrozměrné navety $\mathrm{v}$ barvě stříbra i zlata, $\mathrm{v}$ počtu více než dvaceti kusů, pocházející z oblastí severního Slovenska a datované do konce 19. století. Tento celek byl určen v roce 1989 Karolem Strelcem ${ }^{45}$. Početná je i skupina menších kruhových knoflíků v podobě prolamovaných rozet ve středu doplněných menší pyramidovou rozetou nebo soubor polokulovitých stříbrných knoflíků zhotovených technikou filigránu, které jsou zastoupeny celkem 14 kusy různých velikostí a kompozice. Vrchol knoflíku je ukončen bud' rozetou, někdy vícevrstevnou, a kuličkou, nebo drobnou rozetkou pyramidového tvaru. (Obr. 5.3, 5.6). Tato forma filigránových knoflíků je typická pro regiony Slovenska i Mad’arska.
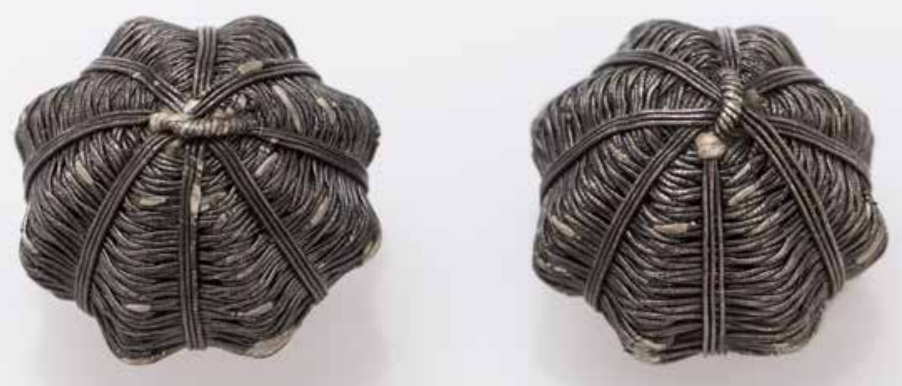

Podobné je to s knoflíky protáhlého kulovitého až oválného tvaru nebo v analogickém provedení polokulovitými knoflíky nazývanými pytike, zakončenými členitou, často dorývanou rozetou a kuličkou. Knoflíky mohou být kanelované od špice k oušku nebo jsou vroubkované do spirá$1 y$, případně doplněné stáčeným drátkem. Vyskytují se v různých velikostech a provedeních od přibližně dvou po sedm centimetrů, celkem sbírka obsahuje 12 kusů. (Obr. 14) Mad’arské vlivy jsou rovněž patrné na masivních litých polokulovitých knoflících zakončených motivem žaludu

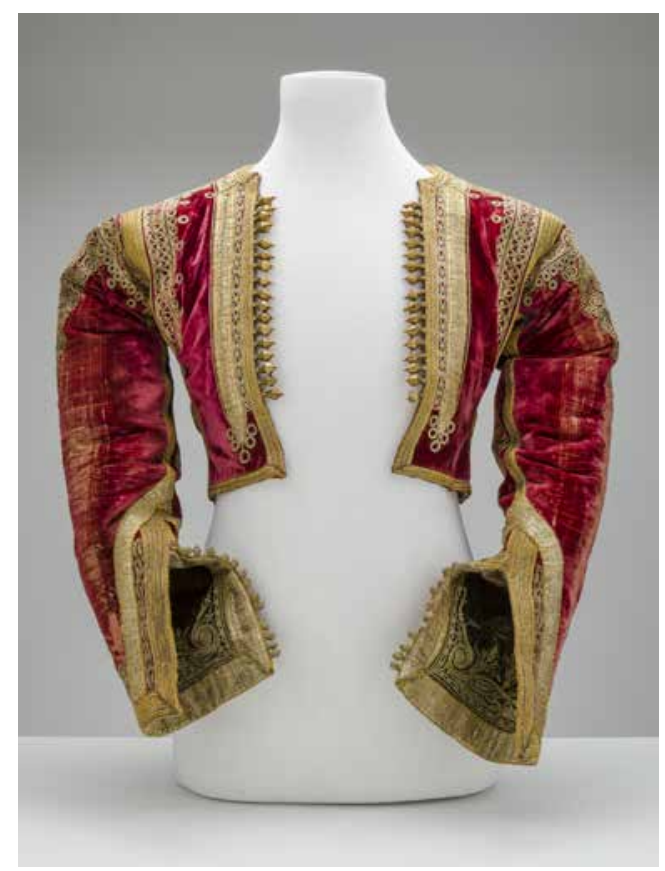

Obr. 16. KABÁTEK ŽENSKÝ W2134, samet, plátěná podšívka, aplikace $z$ dracounu, mosazné knoflíky, Makedonie, 1850-1920, š 1640 x v $410 \mathrm{~mm}$; Sbírka Muzea skla a bižuterie $v$ Jablonci nad Nisou, podsbírka Sbírka Waldes-Knoflíky, foto: Aleš Kosina, 2021
Obr. 14. KNOFLÍK "Pytike” zleva WK1087, lité střibro doplněné stáčeným drátem, Mad'arsko/Slovensko, 1800$1900, \varnothing 57 \mathrm{~mm}$, v $77 \mathrm{~mm}$; Sbírka Muzea skla a bižuterie $v$ Jablonci nad Nisou, podsbírka Sbírka WaldesKnoflíky, foto: Aleš Kosina, 2021

Obr. 15. KNOFLÍKY WK281, střibrný zlacený drát na dřevěné jádru s textilními vlákny, Makedonie, 1850-1920, $\varnothing 19 \mathrm{~mm}, v 14 \mathrm{~mm}$

Sbírka Muzea skla a bižuterie $v$ Jablonci nad Nisou, podsbírka Sbírka WaldesKnoflíky, foto: Aleš Kosina, 2021

45 Zpracování proběhlo v rámci spolupráce se Slovenským národným múzeem v Martine, konkrétně Etnografickým úsekem. 


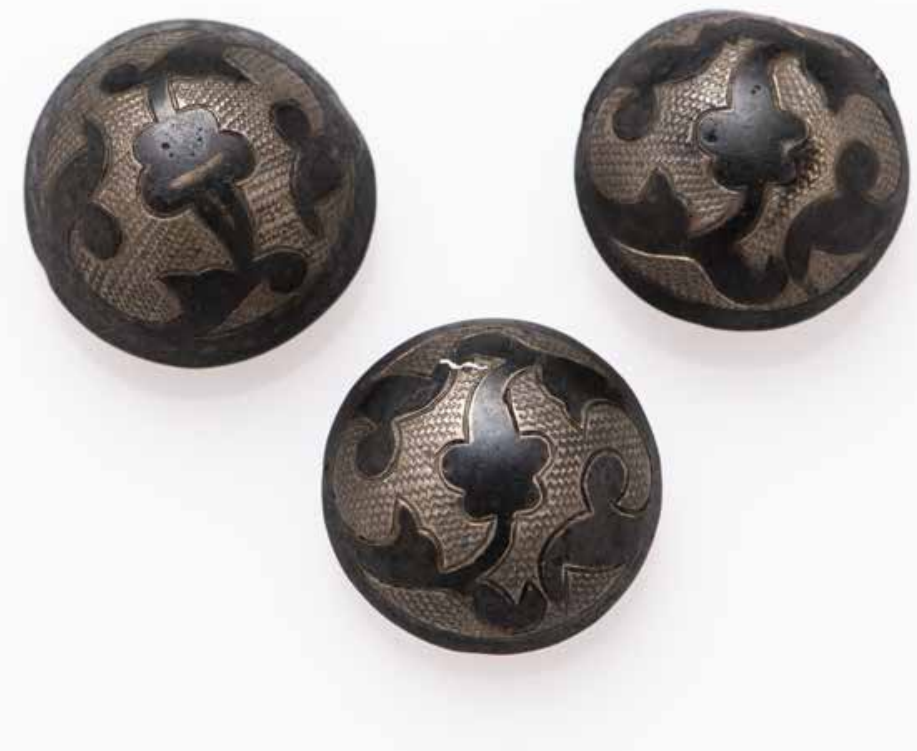

Obr. 17. KNOFLÍKY WK2102, stříbro ražené, nielo, Rusko, 1890-1920, Ø12 mm, v $10 \mathrm{~mm}$; Sbírka Muzea skla a bižuterie $v$ Jablonci nad Nisou, podsbírka Sbírka Waldes-Knofliky, foto: Aleš Kosina, 2021

46 Jedná se o obrazovou prílohu článku Jan Koula, O spinadlech a lidovém kroji česko-slovenském, Zprávy Waldesova musea knoflíkü III, 1918, s. 7. 47 W 2158, Kabátek ženský.

48 W 2157, Vesta ženská. 49 W 2134, Kabátek ženský, W 2135, Vesta mužská. 50 Podobné knofliky jsou součástí sbírky Státního historického muzea v Moskvě: https://catalog.shm.rulentityl OBJECT/5805342?query=\%DO \% 9D\% D0\% 94\%20\% D0\% 94\% D0\% 9CIII-279\%2F92 \&index $=0$ 51 PERRY, Jane. A Collector's Guide to Peasant Silver Buttons. Lulu Press: 2007, s. 34-39. a dubového větvoví, ve Sbírce WaldesKnoflíky jsou i v provedení s kompozitním sklem rubínové barvy.

V prvních letech existence Waldesova muzea se podařilo do sbírky získat několik exemplářù spínadel ze Sedmihradska. Vedle pásů a spon sem patří i knoflíky ze zlaceného stříbra doplněné smaltem a kompozitním sklem $\mathrm{v}$ barvě rubínu. (Obr. 12.2) Jedná se o soubor pěti knoflíků s prostorovou kompozicí do špičky nebo v podobě menších vysoce dekorativních rozet.

Další oblasti jsou zastoupené pouze několika kusy knoflíků, jedná o Dalmácii, Makedonii a Rusko. V kontextu celé dochované sbírky Waldesova muzea jsou další regiony zastoupeny jinými spínadly, především pásovými sponami. Dalmácii zastupují tři velmi specifické filigránové knoflíky vřetenovitého tvaru ze spirálovitě točeného drátku. (Obr. 5.9) Tento typ knoflíků bývá k oděvu připojen háčkem. Na starších vyobrazeních těchto knoflíků ve Zprávách Waldesova muzea jsou háčky připojeny, ale do dnešní doby se nedochovaly u jediného filigránového knoflíku ${ }^{46}$. Další oblast Balkánu, Makedonii, zastupuje kolekce knoflíků ze stř́brných pozlacených drátků, které se vyskytují na mužských krátkých kabátcích. Knoflíky mají uvnitř dřevěné jádro potažené plátnem nebo ovinuté prŕízí. Mohou mít bud' vypouklý kruhový tvar, někdy v podobě rozety (Obr. 15) nebo protáhlý vřetenovitý či oválný tvar, někdy je knoflík doplněn skleněnou perličkou. $\mathrm{V}$ obou př́padech lze v paralelní sbírce objevit dracounem bohatě zdobený ženský kabátek ${ }^{47}$ a vestičku ${ }^{48} \mathrm{~s}$ těmito knoflíky, jež zde mají ryze dekorativní význam. Na dalším ženském kabátku a mužské vestě $\mathrm{z}$ červeného sametu jsou mosazné podlouhlé hranované knoflíky ${ }^{49}(O b r .16)$.

Dvěma různými skupinami knoflíků je zastoupeno Rusko. Jedná se o ukázku tř́ knoflíků z nepravého filigránu zhotovených z raženého polotovaru. Pravděpodobně se jedná o novější nápodoby starších vzorů používaných již v 17. stoletín ${ }^{50}$. Druhou skupinu tvoří velmi specifické knoflíky pro region Kavkazu zhotovené z tepaného stř́bra a zdobené nielem. (Obr. 17) Časté jsou florální nebo fantazijní motivy. Vedle samotných knoflíků jsou v paralelní Sbírce Waldes-Spínadla a oděvní doplňky zachovány pásy dekorované našitými knoflíky obdobného provedení. Je nutné podotknout, že sbírka obsahuje i řadu solitérů i párů s mechanikou manžetových knoflíčků. Jejich dekor tvoří nápis "KAVKAZ“ nebo další upomínkové nápisy. Technikou, materiálem i stylem provedení spadají rovněž do přelomu 19. a 20. století, ale jedná se o oblíbenou a rozšířenou suvenýrovou produkci.

V neposlední řadě je nutné zmínit kolekci Mincooního knoflíku, jako velmi specifickou skupinu spínadel, oblíbenou po celém světě ${ }^{1}$. Celek obsahuje 119 pravých mincovních knoflíků zhotovených druhotnou úpravou skutečných mincí, což bylo provedeno připájením očka. Tyto knoflíky doplňuje soubor sedmi kusů tzv. nepravých mincovních knoflíků, které tento trend ve spínadlech pouze napodobují. Jsou snadno identifikovatelné jednak proto, že nemají reversní stranu, a zároveň nesplňují všechny náležitosti mince. Obvykle se jedná o nápodobu staršího typu mince. V souboru převládají krejcarové mince $\mathrm{v}$ ražbách pro Rakouskou monarchii a Bavorsko, po jednotlivých kusech je to např́íklad 3krejcarová mince Olomouckého biskupství z roku 1670, mince 8 skillingů ražených v Dánsku v roce 1714 nebo 1 groš Olešnického knížectví z roku 1708. Zastoupen je i set knoflíků zhotovených z piastrů používaných 
v Otomanské říši. Pravděpodobně z Bavorska pochází pánská vesta z fialového sametu s drobnými žlutými kvítky, doplněná dvěma řadami celkem čtrnácti mincovních knoflíků ${ }^{52}$, zhotovených $\mathrm{z}$ bavorských desetikrejcarů z roku $1755^{53}$. Vesta je jediným kusem textilu ve sbírce, který ilustruje využití mincovních knoflíků. (Obr. 18)

\section{Závĕr}

Jednou z nejlépe budovaných sbírek fondu Waldesova muzea knoflíků a spínadel byla tzv. Sbírka lidopisná, zaměřená na dokumentaci lidových spínadel, nejen knoflíků, ale také spon, přezek, pásů a souvisejícího textilu. Sbírku doplňoval rozsáhlý tematický obrazový materiál, fotografie i grafiky, které byly rovněž muzeem systematicky shromažd’ovány. Po zrušení muzea a finálního umístění dochované části sbírkového fondu do Muzea skla a bižuterie v Jablonci nad Nisou v roce 1973 došlo k novému rozdělení sbírky, a to na knoflíky a spínadla. Toto rozdělení naprosto neodpovídalo záměru původního Waldesova muzea, jež si z hlediska koncepce práce s knoflíkem kladlo za cíl dokumentovat, zkoumat a vystavovat spínadla souborně dle jejich př́islušnosti k dějinné epoše, kulturnímu okruhu nebo etniku. Knoflíky byly vyčleněny jen tehdy, jednalo-li se o kompaktní celky módních knoflíků 19. a počátku 20. století. Uspořádání na podsbírky Sbírka Waldes-Knoflíky a Sbírka Waldes-Spínadla a oděvní doplňky umožnilo studovat exponáty v nových úhlech pohledu. Studie shrnuje výsledky dlouhodobé práce s první jmenovanou podsbírkou v rámci, kterého se podařilo doplnit nebo zpřesnit zařazení většiny zahrnutých knoflíků k lidovému oděvu. Bylo identifikováno více než 450 solitérů, párů a sad, především z regionů střední Evropy, ale také Nizozemí, Balkánu nebo Ruska. Studie se zaměřuje na představení výraznějších souborů vázaných $\mathrm{k}$ jednotlivým kulturním regionům. Zároveň se snaží upozornit na obtíže se zařazováním některých typů knoflíků do konkrétního

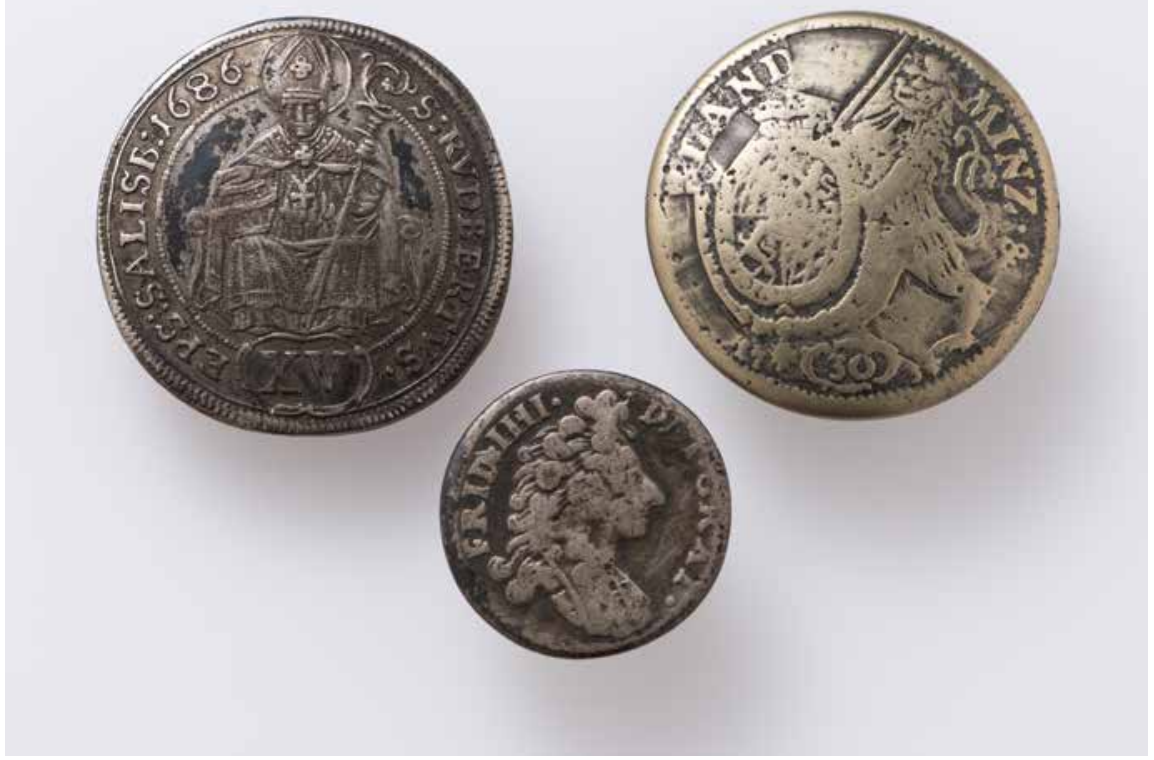

regionu vzhledem k prolínání kultur nebo přesunu etnických skupin. Práce se souborem ukázala, že je vhodné zohledňovat původní vazby mezi oběma rozdělenými celky, a proto bylo ve studii upozorňováno na ukázky textilu nebo doplňky ve druhé podsbírce, jelikož nejlepší způsob, jak lidovému knoflíku porozumět, je zkoumat ho v jeho přirozeném prostředí, tedy na oděvu. Limity vznikajícího sbírkového fondu Waldesova muzea vyvažoval obsáhlý obrazový archiv, který právě v souvislosti se sledovaných tématem přináší řadu zajímavých a využitelných materiálů. Jindřich Waldes chtěl, aby jeho muzeum vytvářelo vhodné zázemí a studijní podmínky pro badatele a vědce zkoumající fenomén knoflíků a spínadel obecně. $\mathrm{V}$ případě lidového knoflíku byl tento cíl naplněn výrazněji než $u$ dalších sbírek, a i dnes může všechen dochovaný materiál dobře posloužit dalším badatelům ve zkoumání lidového knoflíku.

Recenzovaný odborný článek vznikl na základě institucionální podpory dlouhodobého koncepčního rozvoje výzkumné organizace Muzeum skla a bižuterie v Jablonci nad Nisou poskytované Ministerstvem kultury ČR.

\section{Literatura}

BALOG-HORVÁTH, Terézia. Ungarischer volkstümlicher Schmuck, Budapešt: Corvina Kiadó, 1983.

VON GLADIS, Almut. Schmuck im Museum für islamische Kunst, Berlin: Museum für Islamische Kunst, 1998.
Obr. 18. MINCOVNÍ KNOFLÍKY zleva WK1857, zhotovený z mince 15 krejcarů, Max Gandolph von Küenburg, Salzburg, ražené stríbro, pájené mosazné očko, 1686, Ø 28,4 mm; WK1872, zhotovený z mince 8 Skilling, Fridrich IV. z Boží Milosti, Dánsko, ražené stříbro, pájené mosazné očko, 1714, Ø 27,9mm; WK1877, nepravá mince, mosaz, lití, pájené železné očko, $\varnothing 25 \mathrm{~mm}$; Sbírka Muzea skla a bižuterie v Jablonci nad Nisou, podsbirka Sbirka Waldes-Knofliky, foto: Aleš Kosina, 2021

52 W 2152, Vesta pánská. 53 Bavorské kurfiřtství (17531805), Maxmilián III. Josef. 
JOHNOVÁ, Helena. Šperk, Bratislava: Tatran, 1986.

JULIEN, Julien. Die deutschen Volkstrachten zu Beginn des 20. Jahrhunderts, Mnichov: Bruckmann, 1912.

Ǩ̌́IZŽOVÁ, Alena, et. al. Ornament - oděv šperk: archaické projevy materiální kultury, Brno: Masarykova univerzita, 2009.

HRIČKOVÁ, Jitka. Lidový a zlidovělý šperk na severní Moravě a ve Slezsku a jeho zastoupení $v$ muzejních sbírkách (diplomová práce), Brno: Filozofická fakulta Masarykovy univerzity, 2008.

PERRY, Jane. A Collector's Guide to Peasant Silver Buttons. Lulu Press: 2007.

PERRY, Jane. Traditional Jewellery in Nineteenth-Century Europe, London: Victoria \& Albert Museum, 2013.

REITER, Silke. Schmuck zum Gwand, Pforzheim - Mnichov: Bayerisches Nationalmuseum München, 2011.

RITZ, Gislind. Alter Bäuerlicher Schmuck, Mnichov: Callwey, 1978.

SCHÖNWEß, Werner. Der Knopf: Frühe Scheibenknöpfe aus Metall 14.-17. Jh., Bärnau: Deutsches Knopfmuseum Bärnau, 1987.

STEHLÍKOVÁ, Dana. Encyklopedie českého zlatnictví, stříbrnictoí a klenotnictoí. Praha: Libri, 2003.

STRELEC, Karol. Ludové šperky. Bratislava: Osvěta, 1990.

THIELE, Ernst-Otto, et al. Tracht und Schmuck in nordischen Raum, 2. díl. Berlín: Kabitzsch, 1938.
TORANOVÁ, Eva. Šperkárstoo na Slovensku. Bratislava: Pallas, 1976.

Völkerschmuck, Vídeň-Lipsko: Martin Gerlach, 1906.

\section{Články $v$ časopisech}

DOMLUVIL, Eduard. Knoflíky a spony moravských Valachů. Zprávy Waldesova musea knofliků, 1918, ROČ. 3, s. 48-50.

JULIEN, Roza. Knoflík v lidovém kroji, Zprávy Waldesova musea knoflikio, 1916, roč. 1, s. 49-59.

KOULA, Jan. O spinadlech a lidovém kroji česko-slovenském. Zprávy Waldesova musea knoflíkü, 1918, roč. 3, s. 1-9.

Sbírky. Zprávy Waldesova musea knoflíkü, 1918, roč. 3, s. 52.

\section{Internetové zdroje}

Huasnoantoutara, Wikipedia [cit. 31.3. 2021]. Dostupné z: https://de.wikipedia.org/ wiki/Huasnoantoutara

Knoflík. XVII století, Katalog Státního historického muzea v Moskvě [cit. 30. 3. 2021]. Dostupné z: https://catalog.shm.ru/ entity/OBJECT $/ 5805342$ ?query $=\% \mathrm{D} 0 \% 9$ D\%D0\%94\%2\%D0\%94\%D0\%9CIII279\%2F92\&index $=0$

Sedmihradští Sasové, Wikipedia [cit. 5. 3. 2021]. Dostupné z: https://cs.wikipedia. org/wiki/Sedmihrad\%C5\%A1t\%C3\% AD_Sasov\%C3\%A9 